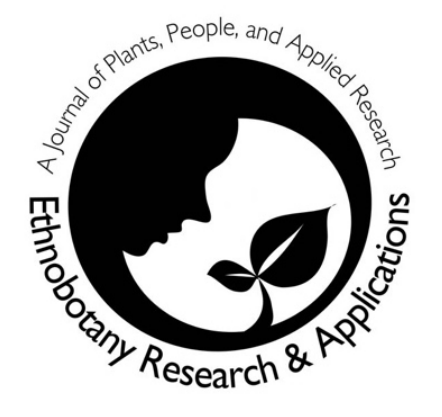

\title{
Etnobotaniczny charakter
}

polskiego Słownika stereotypów i symboli ludowych

Olga Kielak

\section{Repatriation of Ehnobotanical Studies}

\section{Streszczenie}

Tło: Celem artykułu jest przybliżenie czytelnikom etnolingwistycznej metodologii stosowanej przy opisie świata roślin przez zespół lubelskich etnolingwistów skupionych wokół Jerzego Bartmińskiego - pomysłodawcy i redaktora wydawanego od lat 80. XX wieku Słownika stereotypów i symboli ludowych - oraz pokazanie etnobotanicznego charakteru drugiego tomu lubelskiego słownika etnolingwistyczego. Zakreślając obszary wspólne dla etnobotaniki i etnolingwistyki, artykuł otwiera drogę do współpracy dającej satysfakcję przedstawicielom obu dziedzin.

Metody: Wykorzystując metodologię stosowaną w lubelskim słowniku etnolingwistycznym, autorka rekonstruuje metodą definicji kognitywnej hasło mirt (Myrtus communis). Na podstawie zgromadzonego materiału źródłowego (danych leksykograficznych, folklorystycznych i etnograficznych) w definicji kognitywnej mirtu wyodrębnia takie podkategorie semantyczne, jak: kompleksy, kolekcje i ekwiwalencje, wygląd i właściwości, lokalizacja, uprawa i pielęgnacja, zastosowania praktyczne, obrzędowe, magiczne i lecznicze, przepowiednie, wróżby i symbolika, które poprzedza analizą nazw i sposobów kategoryzacji roślin, zgodnie z postulatem podmiotowej rekonstrukcji językowego obrazu świata.

Wyniki: Autorka wypunktowuje wybrane podkategorie semantyczne stosowane w Słowniku stereotypów $i$ symboli ludowych do opisu roślin i objaśnia, w jaki sposób są one rozumiane, dzięki czemu zastosowane fasety mogą zainspirować inne podobne badania w Europie lub na świecie.
Wnioski: Na podstawie przeprowadzonych analiz autorka dochodzi do wniosku, że opisywane w poszczególnych fasetach kwestie składające się na etnolingwistyczną narrację o roślinach w dużej mierze pokrywają się z obszarem zainteresowań etnobotaniki, za punkty wspólne obu dyscyplin uznając: przemiot badań, opisywane przez obie dyscypliny relacje zachodzące między światem roślin i światem ludzi, dowartościowanie roli języka oraz podmiotową wizję świata. Poczynione w artykule rozważania wskazują na możliwość prowadzenia w przyszłości badań interdyscyplinarnych, skupiających lingwistów i botaników.

Slowa kluczowe: etnolingwistyka, etnobotanika, definicja kognitywna, językowy obraz świata

\section{Correspondence}

\section{Olga Kielak}

Instytut Filologii Polskiej, Uniwersytet Marii CurieSkłodowskiej w Lublinie, PI. Marii Curie-

Skłodowskiej 5, 20-031 Lublin, Polska

${ }^{*}$ Corresponding Author:

olga.kielak@poczta.umcs.lublin.pl

\section{Ethnobotany Research \& Applications} 19:46 (2020)

\section{Tło}

W najnowszych ujęciach encyklopedycznych etnobotanika definowana jest następująco:

Ethnobotany is the study of human-plant interactions in their historical and geographical totality. Important questions include how plants are perceived, named, classified, and used; how their interactions with other 
species are understood; and the symbolic and material aspects of their management, harvesting, processing, and use. Studies have often prioritized the cognitive, linguistically encoded, and thus easierto-elicit and easier-to-systematize aspects of knowledge, usually within such specific domains as health, nutrition, agriculture, or resource management, andinlocalcontexts (Alexiades 2018).

Ta dziedzina badań stawiająca sobie za cel badanie kulturowej wiedzy o zasobach biologicznych, prężnie rozwijająca się w obu Amerykach, w wielu częściach Afryki, Azji, Oceanii i w Europie (Alexiades 2018), ma dużo wspólnego z badaniami podejmowanymi w XIX wieku przez polskich etnografów, na co wielokrotnie wskazywali polscy uczeni (Klepacki 2007; Köhler 2014; Łuczaj 2014). „Wyobrażenia, wierzenia i podania o świecie roślinnym" (Rokossowska 1889), „zbiór przesądów o roślinach” (Rostafiński 1895), „poglądy ludu na przyrodę” (Cercha 1904) - takimi określeniami posługiwali się polscy etnografowie końca XIX i początku XX wieku, publikujący artykuły z zakresu ludowej wiedzy dotyczącej pochodzenia roślin, ich wykorzystania w ludowej medycynie i weterynarii, w wierzeniach i rytuałach związanych z obrzędowością doroczną i rodzinną, w magii agrarnej, ochronnej i matrymonialnej, w ludowych wróżbach i przepowiedniach. Ich poszukiwania zbliżone były do tych, które na przełomie XIX i XX wieku podejmowali inni europejscy badacze $z$ kręgu „botaniki ludowej”, zaliczani dziś do pionierów europejskiej etnobiologii, m.in.: niemiecki botanik Heinrich Marzell, duński etnobiolog Vagn J. Brøndegaard, francuski folklorysta Eugène Rolland czy norweski botanik Ove Arbo Høeg (Svanberg \& Łuczaj 2014).

Choć nazwa etnobotanika, zaproponowana przez amerykańskiego botanika Johna W. Harshbergera (Harshberger 1896), pojawiła się w obiegu naukowym już pod koniec XIX stulecia, sam termin zaczął funkcjonować w polskiej literaturze naukowej w II połowie XX wieku. Za pierwsze polskie opracowanie z zakresu etnobotaniki, przygotowane zgodnie z zasadami pracy etnobotanicznej, należałoby jednak uznać nie - jak chcieliby niektórzy autorzy (Kowalska-Lewicka 1964) - książkę Marii Henslowej (1962) poświęconą wybranym roślinom dziko rosnącym w kulturze ludowej, ale badania nad historią roślin uprawnych oraz historią polskich nazw roślin, prowadzone od lat 80 . XIX wieku przez Józefa Rostafiańskiego (m.in. Rostafiński 1880, 1911, 1916), przede wszystkim zaś jego kwestionariusz. Za pośrednictwem ankiety, opublikowanej w kilku polskich czasopismach etnograficznych, Rostafiński otrzymał bogaty materiał informacyjny dotyczący ludowego nazewnictwa roślin, sposobów i historii ich uprawy, rozpowszechnienia poszczególnych gatunków oraz związanych z nimi zwyczajów i wierzeń (Köhler 1993, 2014; Łuczaj \& Köhler 2011). I choć uczony nie określał swoich badań jako „etnobotanicznych”, współcześnie to właśnie jego uznaje się za prekursora polskiej etnobotaniki (Köhler 2014). Pisząc o początkach polskiej etnobotaniki, wypadałoby także wspomnieć Józefa Gajka, etnografa i redaktora Polskiego Atlasu Etnograficznego (Gajek 1946, 1974, 1981), w którym po raz pierwszy zmapowano wiele zjawisk etnobotanicznych w Polsce i który dziś uznawany jest za jeden $z$ najbardziej fascynujących i pionierskich projektów w etnobotanice europejskiej (Łuczaj 2014).

Współcześnie polska etnobotanika prężnie się rozwija, o czym świadczą podejmowane w ostatnich latach inicjatywy, m.in. powstanie w 2011 roku czasopisma „Etnobiologia Polska”, poświęconego etnobotanice, etnozoologii i etnomykologii, liczne konferencje oraz artykuły polskich badaczy, publikowane w międzynarodowych prestiżowych periodykach. W związku z tym, że bogate dokonania polskiej etnobotaniki były już przedmiotem naukowych refleksji (zob. np. Klepacki 2007; Łuczaj 2013), w artykule ograniczę się jedynie do przywołania kilku przykładowych prac z zakresu etnobotaniki i etnomykologii, opublikowanych w ostatnich latach przez Łukasza Łuczaja, Piotra Köhlera, Piotra Klepackiego, Monikę Kujawską i Joannę Typek (zob. np. Köhler 1993, 2014, 2018; Łuczaj 2011; Kujawska, Łuczaj \& Typek 2015; Kujawska, Klepacki \& Łuczaj 2017).

Po lekturze polskich opracowań etnobotanicznych dostarczających wiedzy, w jaki sposób człowiek włącza rośliny w granice swojego świata i w jaki sposób nadaje im znaczenia symboliczne zorientowany antropologicznie językoznawca dochodzi do wniosku, że etnografowie, botanicy, farmakolodzy i etnolingwiści mówią w dużej mierze o tym samym - posługując się w analizach odmiennym aparatem naukowym i akcentując w swoich badaniach odmienne aspekty tych samych zjawisk. W artykule, przybliżając czytelnikom metodologię stosowaną przez opisujących rośliny etnolingwistów, chcę pokazać obszary wspólne dla etnobotaniki i etnolingwistyki, które - przynajmniej w moim odczuciu - otwierają drogę do dającej satysfakcję obu stronom współpracy.

\section{Podstawa materiałowa i metodologia}

W słownikach języka polskiego etnolingwistyka (gr. ethnos 'lud', 'plemię', 'naród', łac. lingua 'język') jest definiowana jako dziedzina językoznawstwa, która zajmuje się badaniem związków języka i kultury. Skupiająca uwagę na „kulturze w języku”, zmierza - 
zdaniem Jerzego Bartmińskiego - do „podmiotowej rekonstrukcji obrazu świata" utrwalonego w języku, bada językową konceptualizację świata (tj. sposoby organizowania treści poznawczych w języku) oraz kulturowe aspekty reguł gramatycznych, składni zdania i tekstu (Bartmiński 2002). Tak prowadzone badania nad językiem pozwalają dotrzeć do człowieka oraz do właściwego mu sposobu pojmowania świata.

Etnolingwistyczny program badań J. Bartmińskiego, dla którego inspiracji należałoby szukać w niemieckim i amerykańskim językoznawstwie antropologicznym (Wilhelm von Humboldt, Edward Sapir, Benjamin Lee Whorf), w etnograficznym podejściu Bronisława Malinowskiego, w semantyce uprawianej przez Annę Wierzbicką, w pracach rosyjskich semantyków, dialektologów i etnolingwistów (Jurija Apresjana, Władimira N. Toporowa czy Nikity I. Tołstoja) czy wreszcie - w publikacjach rodzimych dialektologów i folklorystów (Kazimierza Moszyńskiego, Bernadra Sychty czy Hanny Popowskiej-Taborskiej) - znalazł zastosowanie w wydawanym od lat 70 . XX wieku Słowniku stereotypów i symboli ludowych.

W ciągu półwiecza opublikowano nie tylko eksperymentalny Zeszyt próbny Słownika ludowych stereotypów językowych (Bartmiński 1980), ale także cztery zeszyty pierwszej (z zamierzonych siedmiu) części poświęconej kosmosowi (cz. 1: Niebo, światła niebieskie, ogień, kamienie - 1996; cz. 2: Ziemia, woda, podziemie - 1999; cz. 3: Meteorologia - 2012; cz. 4: Świat, światło, metale 2012) oraz cztery zeszyty poświęcone roślinom (o czym w kolejności)

Celem słownika jest dokonana metodami etnolingwistyki i folklorystyki rekonstrukcja tradycyjnego, opartego na stereotypach i symbolach, obrazu świata i człowieka, stanowiącego klucz do poznania kultury, obecnej w niej pewnej postawy wobec świata oraz swoistej mentalności (Bartmiński 1996). Lubelski słownik etnolingwistyczny proponuje podejście interdyscyplinarne, stosując aparat językoznawczy do analizy tekstów folkloru (Bartmiński 1996).

Stosowaną w słowniku metodologię należałoby sytuować w paradygmacie etnolingwistyki kognitywnej (Tabakowska 2001, 2013; Zinken 2009; Głaz 2013). Zgodnie z założeniami metodologicznymi Słownika stereotypów i symboli ludowych (Bartmiński 1980, 1996, 2005, 2006, 2007, 2009, 2011a, 2016), poszczególne wyobrażenia odtwarzane są metodą zaproponowanej przez J. Bartmińskiego definicji kognitywnej, która „za cel główny przyjmuje zdanie sprawy ze sposobu pojmowania przedmiotu przez mówiących danym językiem, tj. ze sposobu utrwalonej społecznie i dającej się poznać poprzez język i użycie języka wiedzy o świecie, kategoryzacji jego zjawisk, ich charakterystyki i wartościowania" (Bartmiński 1988).

Autorzy poszczególnych haseł układają stereotypowe sądy tworzące wyobrażenia na zasadzie koniunkcji cech w dające się wyodrębnić ze zgromadzonego materiału podkategorie semantyczne nazywane fasetami. Kwintesencją hasła jest to, co znajduje się w „kapsule” najważniejsze, najsilniej utrwalone charakterystyki definiowanego obiektu. Po „kapsule” zamieszczany jest zwykle wstęp ogólnokulturowy, umożliwiający konfrontację polskich wyobrażeń definiowanych obiektów z ich wyobrażeniami funkcjonującymi w innych kulturach świata. Za zasadniczą część opisu uznawana jest eksplikacja zrekonstruowana na bazie zgromadzonej dokumentacji oraz część dokumentacyjna w układzie gatunkowym, obejmująca wariantywne bloki kontekstów z nadpisanymi motywami, które po przeniesieniu do eksplikacji, opatrzone odsyłaczami do numeracji jako stereotypowe sądy o przedmiocie - budują definicje opisywanych wyobrażeń.

Choć uprawiana przez skupionych wokół J. Bartmińskiego językoznawców etnolingwistyka na plan pierwszy wysuwa język (dane systemowe i teksty, jako manifestacje systemu językowego), zaraz za nim w obszarze zainteresowań badaczy znajdują się wierzenia i praktyki, pozwalające usytuować dane językowe w szerszym kontekscie kulturowym. To znaczące przesunięcie granic opisu lingwistycznego, krytykowane przez niektórych językoznawców, np. Macieja Grochowskiego (1993), stanowi jeden z wyznaczników lubelskiej etnoligwistyki. W słowniku preferowany jest bowiem opis holistyczny (Niebrzegowska-Bartmińska 2014), tj. łączna analiza danych językowych, tekstowych i „przyjęzykowych”, tj. ludowych wierzeń i praktyk, stanowiących jedną całość zarówno z naukowego punktu widzenia, jak i w wyobrażeniach nosicieli kultury ludowej (Tołstoj 1992).

W konsekwencji, za podstawę materiałową autorzy przyjmują trzy rodzaje danych: (a) dane leksykograficzne, wyekscerpowane ze słowników języka polskiego, słowników frazeologicznych, słowników synonimów i antonimów, słowników i atlasów gwarowych oraz ze słowników etymologicznych; (b) dane folklorystyczne, tj. różne gatunki tekstów, począwszy od tzw. „małych form”, takich jak zagadki, przysłowia, przepowiednie pogody, przez formy poezji magicznej: zamówienia i zaklęcia, rymowanki i wyliczanki dziecięce, modlitwy i modlitewki; w kolejności: obrzędowe pieśni ludowe 
(doroczne i rodzinne), teksty z dialogów i widowisk oraz przemowy (noworoczne, weselne), baśnie, mity kosmogoniczne i bajki ajtiologiczne, podania i legendy, anegdoty, opowieści wierzeniowe i wspomnieniowe, relacje potoczne i pisaną poezję chłopską oraz (c) dane etnograficzne, tj. zapisy wierzeń i opisy praktyk, zarówno materiały wynotowane z XVIII, XIX- i XX-wiecznych źródeł etnograficznych, jak $i$ te zapisane w ostatnich latach przez członków zespołu etnolingwistycznego.

Przy poszczególnych opisach stosuje się całościowe podejście panchroniczne, które - w opozycji do podejścia synchronicznego czy diachronicznego znosi podziały czasowe i powala na prezentowanie pewnych uogólnionych charakterystyk (Łozowski 1999).

Drugi, poświęcony roślinom, tom lubelskiego Słownika stereotypów i symboli ludowych z całą pewnością określić można opracowaniem etnobotanicznym. Do tej pory ukazały się cztery zeszyty opisujące świat roślin: Zboża (2017), Warzywa, przyprawy, rośliny przemysłowe (2018), Kwiaty (2019) oraz Zioła (2019), cztery kolejne, poświęcone drzewom owocowym i iglastym, drzewom liściastym, krzewom i krzewinkom oraz skupiskom roślin, chwastom i grzybom, znajdują się w przygotowaniu. Deklaracja dotycząca proponowanych jednostek opisu opublikowana została we wstępie do pierwszego zeszytu roślinnego:

Opisując pole roślin, idziemy w naszym Słowniku tropem lingwistów zorientowanych antropologicznie, pytamy o tradycyjny chłopski, szerzej: ludowy obraz świata roślin, o ludową konceptualizację tego świata. Ma ona charakter realistyczny $i$ mitologiczny zarazem. Dla społeczności wiejskiej, rolniczej, z wszystkich roślin w pierwszej kolejności najważniejsze są zboża $i$ warzywa, bo służą zaspokajaniu elementarnych życiowych potrzeb człowieka, w kolejności zioła $i$ kwiaty, krzewy $i$ drzewa, a na peryferiach pola semantycznego są sytuowane grzyby i chwasty. W takiej kolejności układamy tematykę zeszytów w tomie Rośliny (Bartmiński 2017: 10).

\section{Wyniki i dyskusja}

Etnobotanika w etnolingwistyce, czyli kognitywny opis roślin

Aby pokazać, na czym polega etnobotaniczny charakter drugiego tomu lubelskiego słownika etnolingwistyczego, zaprezentuję zrekonstruowane metodą definicji kognitywnej hasło mirt (Myrtus communis), będące jednym z opracowanych przeze mnie haseł z pola leksykalnego „krzewy”.
Prezentowane hasło składa się z „kapsuły”, wstępu ogólnokulturowego oraz eksplikacji.

Na podstawie zgromadzonego materiału źródłowego w definicji kognitywnej mirtu wyodrębniłam takie podkategorie semantyczne, jak: kompleksy, kolekcje i ekwiwalencje, wygląd i właściwości, lokalizacja, uprawa i pielęgnacja, zastosowania praktyczne, obrzędowe, magiczne i lecznicze, przepowiednie, wróżby i symbolika, poprzedzone analizą nazw i sposobów kategoryzacji roślin, zgodnie z postulatem podmiotowej rekonstrukcji językowego obrazu świata. Eksplikacja mirtu pozwoli czytelnikom zorientować się w „wypełnieniu” poszczególnych faset, wydzielanych w słowniku przy opisach roślin. Choć w SSiSL poszczególne hasła składają z dwóch części: eksplikacji i dokumentacji, połączonych systemem numerycznych odsyłaczy umożliwiających weryfikację charakterystyk przywoływanych w części eksplikacyjnej, na potrzeby artykułu obie części zostały scalone fragmenty tekstów pojawiają się bezpośrednio w eksplikacji.

\section{Językowo-kulturowy obraz mirtu (Myrtus communis)}

Mirt, niewielki krzew lub roślinę doniczkową o zielonych liściach i białych kwiatach, hodowano dawniej w domach, w których zamieszkiwały dziewczęta, i w przydomowych ogrodach; uprawa i pielęgnacja mirtu aż do zamążpójścia leżała w gestii panny. W niektórych rejonach Polski z "dobrego wzrostu" rośliny wróżono dziewczynie rychłe lub późne zamążpójście; jednocześnie uważano, że tam, gdzie mirt rośnie (kwitnie), zdarzy się nieszczęście, a dziewczyna pozostanie starą panną.

$\mathrm{Na}$ polskiej wsi mirt wykorzystywany był powszechnie w obrzędowości rodzinnej (chrzcinowej, weselnej i pogrzebowej) oraz dorocznej; pojawiał się także podczas uroczystości katolickich, np. przy komunii świętej czy prymicji. W kulturze tradycyjnej roślina ta symbolizuje czystość i niewinność, $z$ tego powodu przystrajano nią nowożeńców oraz zmarłych przedwczesną śmiercią, dzieci niesione do chrztu lub przystępujące do pierwszej komunii świętej oraz nowo wyświęconych duchownych - jako osoby czyste i niewinne. Wiązana z mirtem panieńskość, dziewictwo i młodość pojawia się w tekstach ludowych pieśni, np. gdy panna prosi, aby chłopiec nie połamał jej grzędy u lawendy i nie podeptał mirty, to chce, aby uszanował on jej dziewictwo.

W kulturach śródziemnomorskich mirt był symbolem odrodzenia mocy witalnych, płodności, miłości i seksu; wiązano go z babilońską boginią Isztar, grecką Afrodytą, rzymską Wenus/Wenerą; 
poświęcano go również Demeter, Apollinowi, ze względu na związek ze śmiercią - także Hadesowi. Wiecznie zielony mirt uchodził za symbol nieśmiertelności. Już $\mathrm{w}$ czasach antycznych $\mathrm{z}$ wydzielających przyjemny zapach liści mirtu przyrządzano olejek eteryczny, wykorzystywany w celach leczniczych; z mitrowych jagód przygotowywano zaś wino (Kopaliński 1985; Forstner 1990; Kowalski 1998).

Z mirtu wyplatano wieńce, które w kulturach indoeuropejskich pełniły funkcję apotropeiczną, pozwalały na przejście od fazy rytualnej śmierci do nowej postaci i nowego statusu, stąd wkładano je na głowy nowożeńcom i zmarłym (Bächtold-Stäubli 1927-1941; Kowalski 1998).

W starożytnym Iranie i na Bliskim Wschodzie mirt uchodził za symbol nieśmiertelności i witalności, poświęcano go bogini miłości i wojny Isztar. Był używany przez starożytnych Asyryjczyków w leczeniu egzemy, ran i wrzodów; w Turcji i w Indiach sproszkowane liście mirtowe stosowano w leczeniu otwartych ran (Dafni 2016). Już od czasów starożytnych mirt uchodził za najważniejszą „roślinę ślubną" we wszystkich religiach starożytnego Wschodu i rejonu Morza Śródziemnego (Dafni et al. 2019).

W Afryce mirt, uważany za symbol wieczoności, używany był w obrzędach pogrzebowych (Dafni 2016; Dafni et al. 2019).

Talmud babiloński określa raj jako „ogród mirtowy” (Dafni et al. 2019); Muzułmanie wierzyli, że gałązki mirtu otrzymuje człowiek przed wrotami Raju; mirt pachnie rajem, a miecz Mahometa został wykonany z liści mirtów rosnących w raju, przyniesionych na ziemię przez Adama (Dafni 2016; Dafni et al. 2019).

Starożytni Grecy i Rzy mianie uważali mirt za symbol dziewiczego wdzięku, poświęcając roślinę bogini piękna i miłości, Afrodycie (Wenus). W mitologii greckiej mirt, roślina Afrodyty, był pierwszym strojem bogini, która ukryła się za mirtowym krzewem. Roślinę tę sadzono zwykle wokół świątyni bogini, a wtajemniczeni uczestnicy kultu Afrodyty nosili na głowach mirtowe wieńce. Ponieważ wiecznie zielony mirt był również poświęcony Persefonie, bogini świata podziemnego, roślina ta pojawiała się w zwyczajach związanych ze śmiercią i pogrzebem, np. mirtem przystrajano groby, mirtem i majerankiem - ozdabiano łoża żałobne. W starożytnej Grecji panny, na znak miłości i okresu narzeczeństwa, nosiły na głowie mirtowe wianki, wkładano je na głowy także młodym małżonkom. Początkowo mirt, funkcjonujący w wyobrażeniach starożytnych Greków jako symbol miłości, biało kwitnący - jako symbol pokoju, obyczajności i dziewiczej urody, stał się później symbolem niewolnictwa i rośliną nagrobną (Bächtold-Stäubli 1927-1941; Forstner 1990; Kowalski 1998; Dafni 2016).

Także w starożytnym Rzymie mirt był symbolem pokoju i miał powiązania ze sferą śmierci - legiony rzymskie, wracające z wyprawy, na której udało się nie przelać zbyt wielkiej ilości krwi (i nie skalać się kontaktem ze śmiercią), zdobiły się gałązkami mirtowymi lub mirtowymi wieńcami. Rzymski historyk Pliniusz pisał, że napój z mirtu oczyszcza żółć, z tego powodu podanie go po porwaniu Sabinek uspokoiło wzburzone umysły i doprowadziło do pojednania zwaśnionych stron. Dawnym Grekom i Rzymianom znane były mirtowe wieńce. Plutarch wspominał o zwyczaju przyozdabiania głów wieńcami mirtowymi podczas wesołych uczt, były one bowiem znakami radości; przy podobnych okazjach obnoszono wśród biesiadników gałązkę mirtową, aby zachęcić ich do śpiewu - osoba, która rozpoczynała śpiew albo śpiewała solo, brała do ręki mirtową gałąź i obchodziła z nią wkoło uczestników zabawy. W antycznej Grecji i Rzymie mirtowe (lub oliwne) wieńce nakładano na głowę zmarłemu, a uczestniczący w obrzędach pogrzebowych żałobnicy przybierali nimi głowy. Wieńce te "gwarantowały zmarłym spokój w grobie, a w stosunku do żywych spełniały funkcję obronną, pomagającą cierpiącym w pogodzeniu się z losem" (Forstner 1990; Kowalski 1998).

W Starym Testamencie gałązki mirtu pojawiają się (obok innych gałęzi) podczas żydowskiego Święta Namiotów, upamiętniającego odzyskanie przez Izraelitów wolności. Wówczas to wyplatano mirtowe wieńce, którymi ozdabiano domostwa; wieńce te nie tylko symbolizowały sytuację świąteczną, ale także zabezpieczały przed niepożądanym spotkaniem z demonami. W księgach Starego Testamentu mirt jest oznaką radości, ma wyobrażać Izrelitów, który dotrzymali wierności Bogu. W Księdze Izajasza wymieniany jest wśród drzew mesjańskiego ogrodu rozkoszy, który ma rozkwitnąć na pustyni, pośród ciernistych zarośli; w Księdze Zachariasza Anioł Pański obwieszcza Zachariaszowi radosną nowinę o odbudowaniu Jerozolimy i świątyni wśród mirtów w dolinie. W tradycji żydowskiej mirtowe wieńce zdobiły głowy nowożeńców. Od hadas 'mirt' pochodzi imię królowej Estery (Hadassah), pięknej, pełnej wdzięku i czystości dziewiczej wybawczyni Izraela, zaś w języku asyryjskim słowo hadasatu oznacza narzeczoną. We współczesnym judaizmie wśród niektórych Żydów sefardyjskich mirt jest nadal używany podczas ceremonii obrzezania (Bächtold- 
Stäubli 1927-1941; Forstner 1990; Kowalski 1998; Dafni 2016).

W kulturze chrześcijańskiej mirt, jeden ze znaków dziewictwa, jest wiązany z Matką Boską; według św. Grzegorza, symbolizuje wstrzemięźliwość, opanowanie oraz współczucie wobec niedoli bliźniego (Forstner 1990; Kowalski 1998).

W tradycji germańskiej mirt kojarzony jest z młodością i niewinnością. Nazywany „drzewem życia”, był sadzony podczas narodzin dziecka. Wierzono, że mirt, z którego obcina się gałązkę dla obcych lub gałąź/kwiat do wianka dla zmarłych usycha; rozwija się natomiast, gdy ucina się z niego gałązki czy kwiaty do wianka ślubnego, którego nie powinna nosić panna młoda, posiadająca nieślubne dziecko. Starożytni Germanie uważali, że dziewczyna nie powinna pielęgnować mirtu, bo, jak mawiano: Kto uprawia mirt, nie będzie nigdy panną młodą, Gdzie mirt dobrze się rozwija, tam nie będzie umizgów. Powszechnie wierzono, że jeśli mirt kwitnie, jego posiadaczka nie wyjdzie w tym roku za mąż. Uważano, że podarowanie dziewicy mirtu spowoduje, że pozostanie ona niezamężną; za zły znak poczytywano także szybkie zwiędnięcie podarowanych narzeczonym mirtowych drzewek. Kojarzony z młodością mirt wprzęgano także w scenariusz wróżb matrymonialnych. W wieczór wigilijny puszczano na wodę listki mirtu, nadając im imiona panny i kawalera; wierzono, że jeśli listki się zejdą, osoby te wstąpią w związek małżeński. W tradycji germańskiej mirt pojawia się także w obrzędowości pogrzebowej. Uważano, że zakwitnięcie mirtu zapowiada śmierć jednego z domowników. Podczas pogrzebu czuwający przy zmarłym posługiwali się bukiecikiem mirtu w charakterze kropidła, którym kropili nieboszczyka święconą wodą. Gałązki mirtu, użyte w czasie pogrzebu młodego zmarłego, powinno się znowu wsadzić w ziemię, bo, jak wierzono, nadal będą rosły. Mirt wykorzystywano także w ludowej medycynie. Wierzono, że herbata z listków mirtu ze ślubnego wianka jest skutecznym lekarstwem na każdą chorobę; trzy listki mirtu z wianka panny młodej miały skutecznie zwalczać gorączkę. Uważano, że zrobiona z mirtowego drewna wykałaczka chroni przed bólem zębów (BächtoldStäubli 1927-1941).

\section{Nazwy}

Nazwa mirt (Myrtus communis), w polszczyźnie ogólnopolskiej i gwarowej także myrt (Podgórski \& Podgórska 2008), miert (Dejna 1978), mirta (Karłowicz et al. 1952-1953), merta (Karłowicz 19001911), mierta (Wronicz 1995), myrta, merda (Karłowicz 1900-1911), mertyn (Paluch 1988), mertin (Podgórski \& Podgórska 2008), mertyna (Śmiełowski 1967), mirtyl (Karłowicz et al. 19521953); w polszczyźnie ludowej, głównie w ludowych pieśniach, zdrobniale mirtka, mertka, mirteńka, mirteczka (Rogowska 1998), miyrcik (Kąś 20152018) - wywodzi się z łac. myrtus < gr. mýrtos (Bańkowski 2000). W tekstach pieśni, pochodzących z terenów ostródzko-warmińsko-mazurskich, mirt nazywany jest także rutą, rutką, ruteczką (Dubisz 1977).

\section{Kategoryzacje}

W słownikach języka polskiego (także gwarowych) mirt definiowany jest jako krzew, krzak. Hodowany w doniczkach na parapetach oraz w przydomowych ogrodach, zaliczany jest do kwiatów, kwiatków doniczkowych, (ozdobnych) roślin doniczkowych. Inne, rzadziej spotykane nazwy mirtu, niosące ze sobą człon kategoryzujący, to: mirtowe drzewo (Karłowicz et al. 1952-1953), na Orawie kalwaryjskie ziele (Kąś 2011).

\section{Kompleksy, kolekcje i ekwiwalencje}

W przemowach i pieśniach weselnych mirt najczęściej łączony jest (a niekiedy występuje wymiennie) z kwiatami i ziołami związanymi z panieńskością i dziewictwem, m.in. z rozmarynem (Rosmarinus), por. panna młoda wyławia prawą rączką wianek, który wpadł do studni, z wianka wylatują dwie równianki (tj. gałazki) mirtu i dwie rozmaranu (tj. rozmarynu) (Bartmiński 2011b); lawendą (Lavandula), por. dziewczyna prosi, aby chłopiec nie połamał jej grzędy u lawendy i nie podeptał mirty [= uszanował jej dziewictwo] (Kolberg 1969); fuksją (Fuchsia), por. obawy kawalera, że smędzące na Śląsku kominy zasmędzą okienko, merty i fuksyje, z czego moja dzioucha wiynuszek uwije? (Dygacz 1987) czy rutą (Ruta graveolens), którą - podobnie jak mirt - sieje w pieśniach panna, które chce wyjść za mąż (Hrycyna 2019).

\section{Wygląd i właściwości}

Mirt ma błyszczące, ciemnozielone liście (Szymańska 1991), zaliczany jest do roślin wiecznie zielonych (Drabik 1990), stąd w tekstach folkloru mowa o zielonym mircie (Bartmiński 2011b; Szymańska 2012). Ze względu na jego niewielkich rozmiarów liście, jest w tekstach ludowych pieśni charakteryzowany jako drobny (powsz.), np.: Mój wianeczek jest zielony, z drobnej mirty uwiniony (Bystroń 1927). Mirtowe liście są delikatne i zasuszone, łatwo się kruszą, stąd w pieśni weselnej panna młoda przed błogosławieństwem prosi: Rozścielaj, mamo, obrusy pod nogi dla córki swej, niech z wieńca mirt sie nie kruszy, który upletli jej (Bartmiński 2011b). 
Mirt ma białe kwiaty, co utrwala jedna z lubelskich pieśni weselnych: Stoi mirta $w$ oknie, białe kwiaty puszcza, dziś nasza Marysia panienstwo opuszcza (Bartmiński 2011b).

Liście rośliny, roztarte $\mathrm{w}$ palcach, wydzielają przyjemny zapach, charakterystykę tę utrwalają pieśni weselne, w których pachnący miyrcik z wianeczka panny młodej zapachniał uczestnikom wesela (Jasiennik Stary 1977). Z uwagi na charakterystyczny zapach mirtu, sporadycznie okadzano nim nieboszczyka, ,aby nie było swądu od zmarłego" (Paluch 1985), zob. zastosowania obrzędowe.

\section{Lokalizacja}

Mirt uprawiany był w doniczkach na oknach, por. w pieśni stoi mirta w oknie (Bartmiński 2011b) jako roślina ozdobna oraz w przydomowych ogrodach (Kolberg 1883/1962).

\section{Uprawa i pielęgnacja}

Mirt hodowano w domach, w których były dziewczęta (Udziela 1890) z przeznaczeniem na przyjęciny, tj. na komunię świętą (Łęga 1933) lub do wesela. Zwykle to w gestii panny leżała uprawa i pielęgnacja tej rośliny „aż do zamążpójścia” (Łęga 1933), na wianek ślubny (Burszta 1967), stąd w pieśniach weselnych panna drobno sieje mirt (Płatek 1976), podlewa go rosą (Janicka-Krzywda 2001).

W Wielkopolsce z okazji urodzin każdego dziecka sadzono doniczkę mirtu, bo, jak wierzono, każde dziecko powinno mieć swoją mertę. Przed ślubem pannie wito wianek $z$ posadzonego specjalnie dla niej mirtu, zaś z mirtu kawalera obcinano gałązkę do wstążeczki ślubnej dla pana młodego (Burszta 1967). Uważano, że najlepiej rośnie mirt zasadzony z gałązki, której użyto wcześniej do przyozdobienia stroju panny młodej lub niesionego do chrztu dziecka (Janicka-Krzywda 2001).

Na Kujawach z „dobrego wzrostu” mirtu wróżono dziewczynie rychłe lub późne zamążpójście (Szulczewski 1966); na Lubelszczyźnie mówiono, że jeśli dziewczyna nie jest cnotliwa, doniczka z mirtem uschnie (Niedźwiada 1977). Jednocześnie uważano, że tam, gdzie mirt rośnie (kwitnie), zdarzy się nieszczęście, a dziewczyna pozostanie starą panną, zob. przepowiednie.

Mirtowe gałązki niechętnie wydawano z domu, aby nie wydać szczęścia (Kujawska et. al. 2016). Wierzono, że podarowanie mirtu pannie młodej, która sama nie ma tej rośliny, „odbierze powodzenie u płci przeciwnej pannom z rodziny ofiarodawcy" (Janicka-Krzywda 2001). Na pograniczu polskoukraińskim wierzono, że jak sie pożyczy takiej [mirtu do bukietu], co ona w ciąży je, ten mirt zginie (Wietlin 1988). Uważano także, że cięcie gałązek mirtowych do przyozdobienia trumny lub świec, palonych przy zmarłym, powoduje „usychanie całych krzaków, z których owe gałązki pochodziły" (Gaj-Piotrowski 1967).

\section{Zastosowania praktyczne}

Dawniej znany był mirtynek, tj. wino przyprawione mirtem; por. także mirtowany 'przyprawiony jagodami mirtowemi' (Karłowicz et al. 1952-1953). Z liści i owoców mirtu wyrabiano olejek mirtowy/mirtellowy, używany w lecznictwie (Mayenowa \& Pepłowski 1982).

\section{Zastosowania obrzędowe}

Mirt wykorzystywany był powszechnie w obrzędowości rodzinnej (chrzcinowej, weselnej i pogrzebowej) oraz dorocznej. Pojawiał się także podczas uroczystości katolickich, np. pierwszej komunii świętej czy prymicji

Mirtem przystrajano ubranie niesionegto do c h r z t u dziecka (Janicka-Krzywda 2001); wpinano go do becików, dekorowano nim kapkę, tj. rodzaj kwadratowej białej narzutki na becik (Świątkowska 1978; Kąś 2015-2018).

W dawnym obrzędzie weselnym mirt oraz wianek mirtowy stanowiły atrybut żegnającej się z panieństwem panny młodej. Mirt, najczęściej pod postacią uplecionego z rośliny wieńca, zdobił głowę panny młodej (Udziela 1994; Kąś 2015-2018). Mirtem przystrajano także welon (Dekowski 1988) czy spódnicę panny młodej (Kąś 2015-2018); panna młoda, która była wdową, przypinała zaś gałązkę mirtu lub rozmarynu z prawej strony czepca (Udziela 1994). Gałązką mirtu lub rozmarynu ozdabiano również czapkę, w której młoda mężatka szła w pierwszą po weselu niedzielę lub święto do kościoła na wywód (Udziela 1994).

Bukieciki z gałązek lub kwiatów mirtu, tzw. woniaczki (Podgórski \& Podgórska 2008), plecione przez pannę młodą i druhny w przeddzień wesela, podczas tzw. wieczoru dziewiczego (Kopczyńska-Jaworska 1989), przewiązane białą wstążką i przypięte do klapy marynarki, kurtek lub żakietów nosili: pan młody, którego na Kaszubach i Kociewiu napominano, aby nikomu nie pozwolił nic urwać $z$ bukieciku z mirtu, bo wówczas państwa młodych mógłby ktoś oczarować (Nadmorski [Łęgowski] 1892); starosta, starostowie i swaszki, drużbowie, cała drużyna weselna (Reinfuss 1965; Bartmiński 2011b). Niekiedy panna młoda i druhny przypinały mirtowe bukieciki mężczyznom na znak, że wybierają ich sobie „na towarzyszy przez cały ciąg wesela" (Ciszewski 1886). Mirt ozdabiał także 
kołnierz pytaca weselnego, kapelusz swata, zapraszającego na wesele drużby (Kąś 2015-2018). Mirtem lub rozmarynem dekorowano biały ręcznik, z którym drużba objeżdżał konno wieś, zapraszając na wesele (Burszta 1967). Mirtem druhny upiększały swoje gorsety i staniki (Dekowski 1978).

Przyozdabiano nim również inne rekwizyty związane z obrzędowością weselną, np. podczas zaręczyn mirtem przystrajano stojący na stole krzyż (Karwicka 1979) oraz talerzyk, na którym leżały obrączki (Sychta 1967-1976); ozdabiano nim nadto: rózgę weselną czy korowaj (Bartmiński 2011b), tj. obrzędowe ciasto weselne; na Podhalu - także skrzynię z posagiem, przewożoną do domu pana młodego (Kąś 2015-2018).

Podczas oczepin pannie młodej zdejmowano wianek mirtowy, gałązki mirtu i rozmarynu (Udziela 1994), panu młodemu zaś - odpinano mirtowy bukiecik (Sobierajski 1960). Mirtowe gałązki, zdjęte z głowy panny młodej, zabierali druhnom swaszkowie, zapewniając tym sobie „szczęście do żeniaczki” (Udziela 1994).

Ozdoby z mirtu przysługiwały tylko „dobrze prowadzącym się" nowożeńcom. Uważano, że przeskoczka, tj. dziewczyna upadła, nie powinna mieć we włosach mirtu, a na głowie mirtowego wianka (Udziela 1994). Podobnie mirtowej ozdoby nie mógł mieć pan młody, który miał już dziecko (Burszta 1967).

W obrzędowości pogrzebowej mirt, powszechnie wykorzystywany w obrzędzie weselnym, pojawia się niemal wyłącznie podczas pogrzebu dzieci oraz osób młodych, niebędących w związku małżeńskim (Libera \& Paluch 1993), z jednej strony podkreślając $w$ ten sposób ich młodość i niewinność, z drugiej - czyniąc pogrzeb symbolicznym obrzędem weselnym, na co zwracają uwagę liczni badacze folkloru (Paluch 1985). Przybierano nim głowę zmarłym dziewczętom/pannom (Gaj-Piotrowski 1967; Paluch 1988), niekiedy także kawalerom i dzieciom (Paluch 1988); dzieciom przyczepiano do sukienek mirtowe gałązki (Gaj-Piotrowski 1967), pannom i kawalerom - ozdoby i bukiety z mirtu (Burszta 1967; GajPiotrowski 1967; Libera \& Paluch 1993), ,jak to się czyni w czasie ślubu" (Łęga 1933). Kwiatami mirtu lub jego gałązkami dekorowano trumnę (Gerlich 1984; Libera \& Paluch 1993). W Wirach koło Poznania mirtem okadzano zmarłą pannę (Paluch 1985).

Mirt, podobnie jak wianek mirtowy, pojawia się także podczas innych uroczystości katolickich, np. podczas przyjęcia pierwszej komunii świętej dziewczynkom wkładano na głowę wianek mirtowy (Łęga 1933) i dekorowano im suknie tą rośliną (Libera \& Paluch 1993), chłopcom zaś przyczepiano do piersi przewiązany białą wstążką bukiecik z mirtu (Łęga 1933) lub wkładano mirt w klapę garnituru (Lipiński 1965).

Mirt pojawia sięwobrzędzie prymicyjnym, którego kulminacyjnym momentem jest pierwsza uroczysta msza święta, odprawiana przez nowo wyświęconego księdza. Przed wyruszeniem z domu rodzinnego do kościoła, po błogosławieństwie, rodzice kropili młodego duchownego kropidłem zrobionym z gałązek mirtu lub bukszpanu. Sam prymicjant ubrany był w komżę przybraną gałązkami tej rośliny, a już w kościele na jego głowę uroczyście wkładano wianek mirtowy (Pyla 2004).

Gałązkami mirtu przystrajano nadto gromnicę, święconą w dniu Matki Boskiej Gromnicznej (2 II) (Karwicka 1979); dodawano je do palmy wielkanocnej (Karwicka 1979), niekiedy ozdabiano nimi także święconkę (Libera \& Paluch 1993). Małe gałązki mirtu wplatały we włosy dziewczęta idące w procesji na Boże Ciało (Szeląg 1934).

\section{Zastosowania magiczne}

Mirt, uważany przez lud za afrodyzjak, wykorzystywano w magii miłosnej - uważano, że jeśli dziewczynie uda się włożyć gałązkę mirtu (lub rozmarynu) "chłopcu w odzież na piersiach noszoną", ten „najgorętszą pokocha ją miłością" (Burszta 1967).

Mirt był też dawniej wykorzystywany w charakterze ochronnym przed szkodliwymi skutkami zjawisk atmosferycznych - uważano, że upleciony z niego wianek panny młodej chroni domostwo, w którym jest przechowywany, przed uderzeniem pioruna (Libera \& Paluch 1993); w Żurawcach (Lubelskie) mirtem i barwinkiem ozdabiano krzyżyki z drewna sosnowego, wykonywane i zatykane we wrotach i oknach w wigilię św. Jana Chrzciciela (23 VI) z intencją ochrony przed burzą i gradem (Bartmiński 2011b).

\section{Zastosowania lecznicze}

Mirtem okadzano chorych z obrzękiem twarzy, przy stanach zapalnych skóry, kolkach i chorobach kobiecych (Paluch 1988). Przy chorobach niewieścich stosowano również herbatę $z$ mirtu (Zborowski 1932). Napar z gałązek suszonej rośliny pito także przy schorzeniach układu pokarmowego (Paluch 1988) czy bólach w okolicy serca (Libera \& Paluch 1993), miał bowiem leczyć duszności w piersiach (Kolberg 1876/1963). Mirtowe listki przykładano na bolący ząb (Kantor 1907); w średniowieczu zalecano przykładać je przećiw 
káżdému boleniu (Mayenowa \& Pepłowski 1982). Mazurzy sądzili, że listki mirtu ze ślubnego wianka są skutecznym lekarstwem przy leczeniu zimnicy, tj. febry (Toeppen 1892; Paluch 1988).

\section{Przepowiednie}

Choć powszechną praktyką było sadzenie mirtu w domostwach, w których mieszkały panny, uważano, że tam, gdzie rośnie, nie ma szczęścia (Steuer 1937). W Krakowskiem, w Beskidach, na Orawie i na Podhalu zakwitnięcie mirtu uważano za zapowiedź choroby, śmierci, a niezamężnej dziewczynie staropanieństwa (Fischer 1921; Janicka-Krzywda 2001). Uważano, że z chaty, w której dziewczęta pielęgnują mirt, „rzadko kiedy wychodzą dziewczęta za mąż", stąd w przysłowiach: Kaj sie merty darzóm, tam sie dziywki starzóm; Gdzie się mirty darzą, tam dziewczęta próżno o weselim marzą (Sychta 19671976).

\section{Wróżby}

Mirt wykorzystywano powszechnie we wróżbach matrymonialnych. W wigilię św. Andrzeja (29 XI) panny puszczały na wodę w miednicy lub w talerzu dwie igiełki lub dwa listki mirtu, symbolizujące chłopca i dziewczynę. Uważano, że gdy puszczone na wodę igiełki lub listki zejdą się ze sobą, będzie to wróżbą wesela młodej pary (Gaj-Piotrowski 1967; Pośpiech 1987; Niebrzegowska 2000). Podobne wróżby miały miejsce podczas wieczoru wigilijnego (Pośpiech 1987). W Pilchowie podczas zabawy używano jednego listka mirtowego - jeżeli liść rzucony na wodę wypłynął na środku naczynia, wówczas znak był pomyślny. Gdy utonął, panna miała zostać nadal w stanie wolnym. Na Śląsku w dniu św. Łucji (13 XII) dziewczęta puszczały na wodę dwa listki mirtu - jeden wyobrażający kawalera, drugi pannę; uważano, że jeśli listek symbolizujący kawalera stoi $w$ miejscu, a drugi posuwa się ku niemu, jego miłość jest nieszczera, i na odwrót (Kawalec 1929).

Na całym obszarze Polski popularna była zabawa andrzejkowa, podczas której pod kilkoma talerzami, miskami, filiżankami umieszczano różne przedmioty, w tym mirt. Następnie biorące udział we wróżbach osoby podnosiły talerze i odkrywały ukryte przedmioty. I tak np. węgiel miał być wróżbą żałoby w nadchodzącym roku, chleb - dostatku, sól - łez, pierścień - wesela. Mirt uchodził zaś za wróżbę rychłych zaręczyn, małżeństwa, drużbowania, a niekiedy i staropanieństwa (Knoop 1895; Pośpiech 1987).

\section{Symbolika}

Mirt jest symbolem czystości i niewinności, z tego powodu przystrajano nim dzieci do chrztu czy komunii świętej, nowożeńców oraz zmarłych przedwczesną śmiercią, jako osoby czyste i niewinne. Podobnie jak wianek mirtowy, jest symbolem dziewictwa panny młodej. W pieśniach mirt symbolizuje panieńskość, dziewictwo i młodość dziewczyny, np.: Mirtek hodowała, rosą podlewała. Dziesięć lat minęło, aż się doczekała (JanickaKrzywda 2001); Drobny mirt, drobny mirt, bom go drobno siała, dobry będzie Staszek, bom takiego chciała (Płatek 1976). Gdy panna prosi, aby chłopiec nie podeptał mirty, to chce, aby uszanował jej dziewictwo, por.: Mój Jasieniu miły, nie jedźże my tędy, bo byś my połomał u lawendy grzędy. Rzędy mi połomiesz, mirty mi podepcesz; zdradziłeś mnie, łotrze, a teraz mnie nie chcesz (Kolberg 1969). W pieśniach weselnych mirt funkcjonuje jako symbol stałości, nierozerwalności związku małżeńskiego: Pamiyntojcie, państwo młodzi, ze wos nik nie oswobodzi, ze woz już nik nie ozłoncý bez tyn miyrcik, bez pochnioncý (Kąś 2015-2018).

Jako roślina wiecznie zielona, jest symbolem życia, por. mirt to życie, bo zieluny nawet w zimie (Pelcowa 2017), odradzających się sił witalnych, z tego też powodu pojawia się w sytuacjach obrzędowych związanych z przełomowymi momentami życia, prowadzącymi do odrodzenia się człowieka w nowej roli społecznej (Pyla 2004).

W senniku ludowym mirt oznacza staropanieństwo, coś niedobrego, czyjś pogrzeb, śmierć; zielony mirt wesele, coś dobrego, komunię dziecka (Burszta 1967; Niebrzegowska 1996).

Podobną symbolikę ma wianek mirtowy, który w pieśniach weselnych, zalotnych i miłosnych oraz rodzinnych uchodzi za symbol czystości i niewinności, $z$ tego też powodu wkładano go na głowę pannie młodej (jedynie takiej, która dochowała czystości), dziewczynom zmarłym przedwczesną śmiercią, dziewczynkom przystępującym do pierwszej komunii świętej czy nowo wyświęconym duchownym, jako osobom czystym i niewinnym. W SSiSL wianek mirtowy pojawi się jako osobne hasło (Kielak, w druku).

\section{Charakterystyka zastosowanych podkategorii semantycznych}

W poszczególnych fasetach składających się na definicję kognitywną mirtu znalazły się kwestie związane z nazewnictwem, uprawą, lokalizacją, wykorzystaniem praktycznym, obrzędowym, magicznym i leczniczym rośliny; omówiono rolę mirtu w zwyczajach i obrzędach dorocznych i rodzinnych, całość wieńczy zaś faseta poświęcona symbolice krzewu.

Podkategorie semantyczne wraz z ich treściowym wypełnieniem nie są przez autorów mechanicznie 
wpisywane w definicje poszczególnych haseł, a rekonstruowane dla każdej z opisywanych roślin w ten sposób, aby za ich pomocą wydobyć ukrytą w analizowanym materiale charakterystykę konkretnej rośliny $z$ punktu widzenia nosiciela i uczestnika badanej kultury (Bartmiński \& NiebrzegowskaBartmińska 2013).

W przypadku głogu (Crataegus) w zapisach etnograficznych oraz tekstach folkloru pojawiły się informacje o tym, że wykonana była $z$ niego cierniowa korona Chrystusa, rzadziej - drzewo krzyża; zgromadzony materiał należało jakoś wpisać w całą strukturę hasła, więc zaproponowano fasetę „głóg jako narzędzie Męki Pańskiej”, która nie pojawia się przy innych roślinach. W przypadku ruty (Ruta graveolens) - ze względu na charakter zgromadzonego materiału dokumentacyjnego wyodrębniona została specjalna podkategoria „panieńskie sianie ruty”. To od zgromadzonego materiału dokumentacyjnego zależy, jakie podkategorie uda się badaczowi wyodrębnić. Nie jest więc moźliwe podanie całościowego wykazu faset wraz z ich treściowym wypełnieniem, ponieważ są one miękkie, zależą od charakterystyk konkretnych roślin, a na chwilę obecną nie wszystkie hasła roślinne zostały opracowane.

Poniżej zamieszczono roboczy wykaz wybranych, najczęściej powtarzających się w opisach roślin podkategorii semantycznych wraz $z$ ich uproszczoną charakterystyką. Podobny wykaz faset pojawił się w eksperymentalnym Zeszycie próbnym Słownika ludowych stereotypów językowych (Bartmiński 1980).

\section{Kompleksy i kolekcje}

$\mathrm{W}$ tej fasecie pokazujemy, z jakimi rzeczami i zjawiskami współwystępuje opisywana roślina, pełniąc wspólną funkcję, np. w ludowych pieśniach goździk (Dianthus), jako symbol dziewictwa, współwystępuje z innymi kwiatami/ziołami z wianka dziewczyny, tj. z rumiankiem (Matricaria), rozmarynem (Rosmarinus), mirtem (Myrtus) i różą (Rosa) (Neppop-Ajdačić 2019).

\section{Opozycje}

Ta podkategora semantyczna zdaje sprawę z tego, w jakie opozycje wchodzą opisywane rośliny oraz jaka cecha staje się podstawą przeciwstawienia, np. w zagadce przyjemny zapach fiołka (Viola) jest przeciwstawiany niemiłej woni cebuli (Allium cepa), por. Smaruj Żyda fiołkami, a jego i tak czuć będzie cebulą (Bielak 2019).

\section{Pochodzenie}

W tym miejscu odnotowujemy informacje dotyczące tego, od czego pochodzi lub w jaki sposób powstała roślina, np. zgodnie $\mathrm{z}$ legendą, groch (Pisum) powstał z łez wylanych przez Matkę Boską pod krzyżem, z tego też powodu nazywany jest łzami Matki Boskiej (Bartmiński \& Prorok 2018); bratek (Viola tricolor) zaś w wyniku przemiany z siostry i brata, złączonych kazirodczą miłością (Szadura 2019).

\section{Wygląd i właściwości}

W tym segmencie definicji rekonstruujemy wygląd definiowanej rośliny (wielkość, kolor kwiatów czy owoców) oraz jej właściwości (np. zapach); dla przykładu fragment definicji ogórka (Cucumis sativus) brzmi: jest podłużny, zielony lub żółty, gładki z wierzchu lub pokryty charakterystycznymi chropowatymi wypustkami, jest twardy i chrupiący, wodnisty, ma świeży zapach, jest smaczny (Prorok 2018a).

\section{Czas kwitnienia i zbioru}

W tej fasecie czytelnicy znajdą informacje o okresie kwitnienia rośliny oraz czasie zbierania jej owoców; w przypadku niektórych roślin czas dojrzewania i zbioru owoców był dla użytkowników na tyle ważny, że został utrwalony już na poziomie nazw, np. odmiana dojrzewających w okolicy dnia św. Jana (24 VI) kartofli (Solanum tuberosu) nazywana jest na Lubelszczyźnie świętojankami (Bartmiński \& Bielak 2018).

\section{Uprawa i pielęgnacja}

W tym segmencie definicji opisujemy informacje związane z uprawą opisywanej rośliny, np. kwieste dotyczące siewu, rozsadzania, pielenia, okopywania czy zbioru kapusty (Brassica oleracea) (Prorok 2018b). W przypadku niektórych roślin "kwestie" związane z uprawą i pielęgnacją leżą w gestii konkrentych osób, np. uprawa róż (Rosa) należy do sfery działalności panny, która sadzi je na znak gotowości do miłości (Niebrzegowska-Bartmińska 2019).

\section{Lokalizacja}

Za pomocą tej kategorii semantycznej wskazujemy na miejsce występowania (rośnięcia) opisywanej rośliny, $\mathrm{np}$. lawenda (Lavandula) rośnie zwykle w ogródku, gdzie jest doglądana przez dziewczęta (Prorok 2019a).

\section{Lokalizator}

W tej fasecie umieszczane sa informacje o tym, kto zamieszkuje/przebywa w opisywanej roślinie, np. w ludowych wyobrażeniach w życie (Secale) przebywają liczne istoty demoniczne, m.in. demony polne i zbożone, południce (Bartmiński \& Kaczan 2017). Albo inny przykład: w ludowych pieśniach miłosnych pole, na którym rośnie kapusta (Brassica oleracea), jest miejscem spotkań miłosnych; na 
Kaszubach przenśc bez kapustã oznacza 'zajść w ciążę' (Prorok 2018b).

\section{Święcenie}

Ta kategoria semantyczna przynosi informacje o tym, kiedy i w jakich okolicznościach święcona jest opisywana roślina, np. traktowaną jako zioło cebulę (Allium cepa) święcono wraz z innymi roślinami w dniu Trzech Tróli (I 6) oraz w dniu Matki Boskiej Zielnej (15 VIII) (Bartmiński \& Łaszkiewicz 2018).

\section{Zastosowania praktyczne}

W tej fasecie zamieszczane są informacje dotyczące wszystkich praktycznych zastosowań opisywanej rośliny: w charakterze pożywienia (na surowo lub w sposób przetworzony), surowca do wyrobu sprzętów gospodarskich czy przedmiotów domowego użytku. Za zastosowanie praktyczne może uchodzić barwienie pisanek w wywarze z cebuli (Allium cepa) (Bartmiński \& Łaszkiewicz 2018) lub źdźbłach młodego żyta (Secale) (Bartmiński \& Kaczan 2017), klęczenie na grochu (Pisum) - stosowane dawniej jako narzędzie bolesnej kary dla dzieci (Bartmiński \& Prorok 2018) czy wytwarzanie z marchwii (Daucus carota) dziecięcych zabawek (Prorok 2018c).

\section{Zastosowania obrzędowe}

W tym segmencie definicji pojawiają się informacje o wykorzystaniu opisywanej rośliny w obrzędowości dorocznej (np. bożonarodzeniowej, wielkanocnej, sobótkowej) i rodzinnej (chrzcinowej, weselnej i pogrzebowej), np. słoma jako materiał, z którego wykonywano kukły obrzędowe, m.in. niedźwiedzia czy Marzannę (Bartmiński \& Bielak 2017) czy konopie (Cannabis sativa), z których szyto zmarłym ubiory do trumny (Niebrzegowska-Bartmińska 2018).

\section{Zastosowania magiczne}

Czytelnicy znajdą tu infomacje dotyczące wykorzystania opisywanej rośliny w magii (ochronnej, miłosnej, gospodarskiej), np. okadzaniem chabrem (Centaurea) domostwa z intencją ochrony przed piorunem czy krów w celu zabezpieczenia przed czarownicami (Piekarczyk \& Szadura 2019); karmienie grochem (Pisum) zwierząt, m.in. kur - aby znosiły dużo jajek, koguta aby był żwawy i porządnie piał, czy gołębi - aby nie opuszczały swojego gołębnika (Bartmiński \& Prorok 2018).

\section{Zastosowania lecznicze}

W fasecie tej zamieszczamy informacje dotyczące wykorzystania definiowanej rośliny w ludowym lecznictwie oraz w ludowej weterynarii, $n p$. wykorzystanie grochu (Pisum) przy leczeniu chorób skóry, przypominających kształtem jego ziarna, tj. brodawek, liszajów, odcisków czy obmywanie odwarem z grochu owrzodzonych wymion krów (Bartmiński \& Prorok 2018). Odnotowujemy zarówno praktyki uzasadnione medycznie, jak i zabiegi magiczne, np. przenoszenie choroby na roślinę.

\section{Przepowiednie + wróżby}

Często te fasety pojawiają się łącznie, obie bowiem dotyczą tego, w jaki sposób za pomocą opisywanej rośliny człowiek wnioskuje o przyszłości. Wróżba tym się różni od przepowiedni, że wymaga pewnego działania ze strony człowieka; będziemy z nią mieli do czynienia np. wówczas, gdy dziewczyna, aby dowiedzieć się, co czuje do niej ukochany chłopak, bierze stokrotkę (Bellis) i obrywając jej płatki, wypowiada formułkę: Kocha, nie kocha... (Kaczan 2019). W przypadku przepowiedni sama obserwacja rośliny (np. obfitości owoców na niej) pozwala wnioskować o zamianach zachodzących w świecie, np. duża ilość owoców na wiśni (Cerasus) ma być zapowiedzią urodzaju na kartofle (Solanum tuberosu) (Bartmiński \& Bielak 2018).

\section{Ekwiwalencje}

Opisując rośliny, szukamy ich „kulturowych zamienników", tj. obiektów, które pojawiają się w takich samych funkcjach, np. cebula (Allium cepa) występuje wymiennie z czosnkiem (Allium) jako ulubione warzywo Żyda (Bartmiński \& Łaszkiewicz 2018).

\section{Symbolika}

Faseta ta wieńczy eksplikację, w pewien sposób podsumowuje definicję rośliny, ponieważ symbolika roślin może być wydobywana na różne sposoby, m.in. poprzez analizę etymologii czy tekstowych ekwiwalencji, może też wynikać $z$ konwencji gatunkowych tekstu (Niebrzegowska-Bartmińska). Możemy mieć do czyniania z symbolem prostym, np. róża (Rosa) jako symbol piękna i panieńskiej/kobiecej urody (NiebrzegowskaBartmińska 2019) lub z symbolem złożonym, symboliczną sekwencją, np. w pieśniach miłosnych obraz chmielu (Humulus lupulus), który pnie się po tyczce, w planie znaczeń naddanych symbolizuje akt miłosny (Bartmiński \& Hrycyna 2018).

Wyróżnione kategorie semantyczne poprzedzają dwa segmenty definicji, nie będące fasetami: nazwy i kategoryzacje.

\section{Nazwy}

W tym segmencie definicji znajdują się informacje dotyczące nazw - zestawiane są nazwy gwarowe oraz kwestie związane z etymologią; nie bez powodu w słowniku wychodzimy od nazw, zakładamy, że dane etymologiczne pozwalają nam zhierarchizować charakterystyki roślin zgodnie z założeniem, że w ich nazwach zostały utrwalone cechy istotne dla 
człowieka, np. nazwa kaczeniec (Caltha palustris) utrwala podobieństwo rośliny do młodej kaczki, zaś inne gwarowe nazwy kwiatu utwralają m.in. miejsce rośniecia (bagno), czas kwitnienia - w okolicy dnia św. Wojciecha (23 IV) (wojciech) czy działania lecznicze (kolkownik), bo wierzono, że za ich pomocą można leczyć kolkę sercową (Prorok 2019b).

\section{Kategoryzacje}

W kolejności zestawiamy pojęcia nadrzędne dla definiowanych roślin, co jest o tyle istotne, że wybór hiperonimu determinuje sposób myślenia o przedmiocie (Bartmiński 1990). Kategoria nadrzędna, warunkowana przez punkt widzenia (prezentujący założony typ racjonalności) oraz kształtowaną przez ten punkt perspektywę, ma wpływ na dalszy dobór kategorii semantycznych oraz jakościowe charakterystyki przedmiotu w ramach przyjętych faset (Bartmiński, Niebrzegowska 1998). Jedna roślina, np. bratek (Viola tricolor), może być przez różnych użytkowników języka postrzegana jako kwiat, ziele lub chwast (Szadura 2019), a z przyjętą kategorią nadrzędną będzie wiązał się różny sposób opisu rośliny, który my próbujemy pokazać w sposób scalony.

\section{Wnioski}

Autorzy haseł roślinnych publikowanych w Słowniku stereotypów i symboli ludowych nie są botanikami i w rekonstruowanych segmentach definicji nie opierają się na faktach botanicznych, ale - jak przystało na etnolingwistów - na licznych opracowaniach etnograficznych, dialektologicznych oraz tekstach folkloru słownego. Od pierwszego zeszytu tomu roślinnego uzgadniają jednak swoje ustalenia z konsultentem botanicznym, dr. hab. Robertem Gruszeckim z Katedry Warzywnictwa i Zielarstwa Uniwersytetu Przyrodniczego w Lublinie, aby ze słownika skorzystać mogli nie tylko językoznawcy, kulturoznawcy, folkloryści i etnolodzy, ale także botanicy, zwłaszcza etnobotanicy.

Opisywane w poszczególnych kategoriach semantycznych kwestie składające się na etnolingwistyczną narrację o roślinach w znacznej mierze pokrywają się z obszarem zainteresowań etnobotaniki - pokazują, w jaki sposób człowiek postrzega, nazywa i wykorzystuje rośliny. Część z wyodrębnianych przez nas podkategorii semantycznych pokrywa się $z$ domenami semantycznymi (kategoriami użytkowymi), za pomocą których opisane zostały rośliny w innym polskim kompendium poświęconym florze, tj. w przywoływanej już wcześniej etnobotanicznej publikacji pt. Rośliny w wierzeniach $i$ zwyczajach ludowych. Słownik Adama Fischera (Kujawska et. al.
2016). Jej autorzy ludowe zastosowania roślin podzielili na następujące kategorie użytkowe: zastosowania apotropeiczne, gospodarcze, kosmetyczne, lecznicze, magiczne, obrzędowe, ozdobne, pożywienie (głodowe, funkcjonalne, lecznicze, obrzędowe), używki, weterynaria, wierzenia, zabawki dziecięce.

Choć etnolingwiści rezygnują z opisywania świata za pomocą nomenklatury botanicznej, nad fakty botaniczne przekładając fakty kulturowe, a etnobotanicy raczej nie interpretują zaszyfrowanych w ludowych pieśniach znaczeń naddanych o roślinach, między etnobotaniką a uprawianą w środowisku lubelskim etnolingwistyką istnieje wiele punktów wspólnych. Najważniejszym z nich jest przedmiot badań, który stanowi świat roślinny; oczywiście w przypadku etnolingwistyki obszar zainteresowań rozciąga się na całość tradycyjnego obrazu świata, zaś rośliny stanowią zaledwie jeden z jego wycinków.

Idąc dalej, etnobotanikę interesują relacje zachodzące między światem roślin a człowiekiem (Faulks 1958; Łuczaj 2013) oraz przyczyny zmieniającego się kontekstu wzajemnych kontaktów ludzi i roślin (Alcorn 2003); relacje i przyczyny, których bogactwo i złożoność doskonale ukazują zrekonstruowane metodą definicji kognitywnej językowo-kulturowe obrazy roślin.

Etnolingwistyka i etnobotanika, podobnie jak inne etnometodologie (etnohistoria, etnozoologia, etnoastronimia czy etnomedycyna), nastawione są na badanie myślenia potocznego. Jak słusznie zauważa J. Bartmiński, w nazwie każdej z tych dyscyplin:

człon etno- jest pojmowany podmiotowo, oznacza w pierwszej kolejności określoną społeczność jako twórce i nosiciela pewnej dyscypliny wiedzy, pewnego porządku kulturowego, pewnych form wyrażania się. Odpowiednie dyscypliny naukowe dokonują „rekonstrukcji podmiotowej”, chcą patrzeć na świat oczami członka danej społeczności, odtwarzać jego punkt widzenia. Dopiero na dalszym planie (metaplanie) ta potoczna koncpetualizacja staje się przedmiotem zainteresowania wraz z dokonującym je podmiotem, konceptualizatorem (Bartmiński 2008).

Etnobotanika bada ludową wiedzę dotyczącą roślin, za kluczowe uznając właśnie punkt widzenia i perspektywy miejscowej ludności (Alexiades 2018). Perspektywę emiczną, tj. badanie kultury od strony jej użytkowników, przyjmuje zwłaszcza etnobotanika rozumiana jako etnobologia, zainteresowana sposobem, w jaki ludzie $z$ danego regionu nazywają, kategoryzują, klasyfikują, postrzegają i wykorzystują 
swoje rośliny. Podobnie etnolingwistykę interesuje podmiotowa rekonstrukcja elementów tradycyjnego obrazu świata - nie tyle co oznacza $X$, ile odpowiedź na pytanie: jak ludzie (zamieszkujący konkretne terytorium, tj. cały obszar etnicznie polski) rozumieją $X$.

Obie dyscypliny łączy wreszcie specjalne traktowanie języka - naturalne jak się okazuje nie tylko dla językoznawców, którzy budując opisy roślin, sięgają po twarde „dowody językowe” pozwalające im zweryfikować wiele ze stawianych hipotez, ale i dla etnobotaników, którzy w badaniach często priorytetowo traktują zakodowane w języku aspekty wiedzy (Alexiades 2018).

Co więc różni przedstawicieli obu dyscyplin? Etnolingwiści są przede wszystkim lingwistami dociekają istoty języka, za pomocą którego mówią o roślinach. Nie tylko przywołują w swoich opisach teksty folkloru słownego, zwłaszcza teksty ludowych pieśni, ale - świadomi istnienia metaforycznego języka obrazów, paralel i symboli - próbują je zdekodować i zapisać związane z roślinami sensy naddane (ze świadomością, że formułowanie znaczeń symbolicznych pozostaje zawsze pewną hipotezą).

Choć współczesna etnobotanika pojawiła się w połowie XIX wieku na pograniczu etnologii, archeologii i botaniki i rozwijając się w ciągu następnych dziesięcioleci, w różnym stopniu czerpała z osiągnięć nauk przyrodnicznych i społecznych: agronomii, ekologii, biologii ewolucyjnej, farmakologii, geografii, historii i językoznawstwa, archeologii, etnologii i antropologii, stając się multudyscyplinarną dziedziną badań (Alexiades 2018), pionierzy badań etnobotanicznych byli jednak z wykształcenia przyrodnikami, a współcześnie badania etnobotaniczna podejmowane są głownie przez instytucje botaniczne (Łuczaj 2013).

Tymczasem lektura opracowań etnobotanicznych oraz praca w zespole powołanym do prac nad Słownikiem stereotypów i symboli ludowych skłania do wniosków, że etnobotanika jest częścią etnolingwistyki rozumianej jako dziedzina językoznawstwa zmierzająca do podmiotowej rekonstrukcji obrazu świata utrwalonego w języku i kulturze. Idąc dalej tym tropem, można zaryzykować stwierdzenie, że także inne etnonauki będą miały wiele punktów wspólnych z uprawianą w środowisku lubelskim etnolingwistyką, np. elementy etnomedycyny pojawiają się $w$ fasecie dotyczącej zastosowania czy wykorzystania w ludowym lecznictwie przy opracowanych już definicjach kognitywnych elementów kosmosu i roślin, ujawniają się także w rekonstruowanych definicjach zwierząt; w badania etnomedyczne, obejmujące wierzenia, wiedzę i praktyki określonej grupy kulturowej związane ze zdrowiem wpisuje się praca $\mathrm{M}$. Marczewskiej (2012), poświęcona językowokulturowym wyobrażeniom wybranych chorób; punktem wspólnym etnozoologii i etnolingwistyki będzie ludowa wiedza dotycząca zwierząt oraz relacje ludzi i zwierząt, które zostaną opisane w trzecim tomie SSiSL, poświęconym zwierzętom; na styku świata zwierząt i świata roślin sytuują się etnolingwistyczne badania dotyczące nazw zwierząt w nazwach roślin, podejmowanie m.in. przez J. Waniakową (2015) czy V. Kolosovą i innych (2017).

Uzmysławia to uczonym, że sięgnięcie po prace badawcze z innych dziedzin nauki pozwoli ujrzeć prowadzone przez siebie badania w innym świetle, $z$ innej perspektywy.

\section{Deklaracje}

Lista skrótów: Nie dotyczy

Zatwierdzenie etyczne i zgoda na udział: Nie dotyczy

Zgoda na publikację: Nie dotyczy

Konflikt interesów: Autorka deklaruje, że nie ma konfliktu interesów.

Finansowanie: Praca naukowa finansowana w ramach programu Ministra Nauki i Szkolnictwa Wyższego pod nazwą „Narodowy Program Rozwoju Humanistyki" w latach 2015-2020. Tytuł projektu: „Świat roślin w polszczyźnie ludowej i potocznej (drzewa, zboża, kwiaty, zioła, grzyby itp.). Słownik etnolingwistyczny". Kierownik projektu: prof. dr hab. Jerzy Bartmiński.

Wkład autorów: Nie dotyczy

Podziękowania: Nie dotyczy

\section{Cytowana literatura}

Alcorn JB. 1995. The Scope and Airns of Ethnobotany in a Developing World. Ethnobotany Evolution of the Discipline. Edited by RE Schultes, S von Reis. Chapman, Hall, London, U.K., Pp. 23-39.

Alexiades MN. 2018. Ethnobotany. The International Encyclopedia of Anthropology. Edited by $\mathrm{H}$ Callan. Wiley.

Bächtold-Stäubli $\quad \mathrm{H} \quad$ (ed). 1927-1941. Handwörterbuch des deutschen Aberglaubens. Vol. 1-10. Walter de Gruyter, Co, Berlin und Leipzig, Germany.

Bańkowski A. 2000. Etymologiczny słownik języka polskiego. Vol. 1-2. Wydawnictwo Naukowe PWN, Warszawa, Poland. 
Bartmiński J. 1980. Słownik ludowych stereotypów językowych. Zeszyt próbny. Wydawnictwa Uniwersytetu Wrocławskiego, Wrocław, Poland.

Bartmiński J. 1988. Definicja kognitywna jako narzędzie opisu konotacji. Konotacja. Edited by $\mathrm{J}$ Bartmiński. Wydawnictwo Uniwersytetu Marii CurieSkłodowskiej, Lublin, Poland, Pp. 169-183.

Bartmiński J. 1990. Punkt widzenia, perspektywa, językowy obraz świata. Językowy obraz świata. Edited by J Batrmiński. Wydawnictwo Uniwersytetu Marii Curie-Skłodowskiej, Lublin, Poland, Pp. 109127.

Bartmiński J. 1996. O słowniku stereotypów i symboli ludowych. Słownik stereotypów i symboli ludowych. Vol. 1: Kosmos, Part 1: Niebo, światła niebieskie, ogień, kamienie. Overall concept and chief ed: J Bartmiński, vice-ed: S Niebrzegowska-Bartmińska. Wydawnictwo Uniwersytetu Marii CurieSkłodowskiej, Lublin, Poland, Pp. 9-25.

Bartmiński J. 2002. Etnolingwistyka. Wielka encyklopedia PWN. Vol. 8. Edited by J. Wojnowski. Wydawnictwo Naukowe PWN, Warszawa, Poland, Pp. 380-381.

Bartmiński J. 2005. Jazykovaja kartina mira. Očerki po ètnolingvistike, Indrik, Moscow, Russia.

Bartmiński J. 2006. Językowe podstawy obrazu świata. Wydawnictwo Uniwersytetu Marii CurieSkłodowskiej, Lublin, Poland.

Bartmiński J. 2007. Stereotypy mieszkają w języku. Studia etnolingwistyczne. Wydawnictwo Uniwersytetu Marii Curie-Skłodowskiej, Lublin, Poland.

Bartmiński J. 2008. Etnolingwistyka, lingwistyka kulturowa, lingwistyka antropologiczna? Język a Kultura 20: 15-33.

Bartmiński J. 2009. Aspects of Cognitive Ethnolinguistics. Equinox Publishing Ltd, London and Oakville, U.K.

Bartmiński J. 2011a. Jezik - slika - svet. Etnolingvisticke studije. SlovoSlavia, Beograd, Serbia.

Bartmiński J. (ed). 2011b. Polska pieśń i muzyka ludowa. Źródła i materiały. Vol. 4: Lubelskie; Part 1: Pieśni i obrzędy doroczne; Part 2: Pieśni i obrzędy rodzinne. Instytut Sztuki PAN, Lublin, Poland.

Bartmiński J. 2016. Jazyk v kontextu kultury. Dvanáct statí z lublinské kognitivní etnolingvistiky, Karolinum, Prague, Czech Republic.

Bartmiński J. 2017. Od redaktora. Słownik stereotypów i symboli ludowych. Vol. 2: Rośliny, Part
1: Zboża. Overall concept and chief ed: J Bartmiński, vice-ed: S Niebrzegowska-Bartmińska. Wydawnictwo Uniwersytetu Marii CurieSkłodowskiej, Lublin, Poland, Pp. 7-14.

Bartmiński J, Bielak A. 2017. Słoma. Słownik stereotypów i symboli ludowych. Vol. 2: Rośliny, Part: 1: Zboża. Overall concept and chief ed: J Bartmiński, vice-ed: S Niebrzegowska-Bartmińska. Wydawnictwo Uniwersytetu Marii CurieSkłodowskiej, Lublin, Poland, Pp. 158-187.

Bartmiński J, Bielak A. 2018. Kartofel (Solanum tuberosum). Słownik stereotypów i symboli ludowych. Vol. 2: Rośliny, Part: 2: Warzywa, przyprawy, rośliny przemysłowe. Overall concept and chief ed: J Bartmiński, vice-ed: S Niebrzegowska-Bartmińska. Wydawnictwo Uniwersytetu Marii Curie-Skłodowskiej, Lublin, Poland, Pp. 149-172.

Bartmiński J, Hrycyna E. 2018. Chmiel (Humulus lupulus). Słownik stereotypów i symboli ludowych. Vol. 2: Rośliny, Part: 2: Warzywa, przyprawy, rośliny przemysłowe. Overall concept and chief ed: J Bartmiński, vice-ed: S Niebrzegowska-Bartmińska. Wydawnictwo Uniwersytetu Marii CurieSkłodowskiej, Lublin, Poland, Pp. 493-502.

Bartmiński J, Kaczan A. 2017. Żyto (Secale). Słownik stereotypów i symboli ludowych. Vol. 2: Rośliny, Part: 1: Zboża. Overall concept and chief ed: J Bartmiński, vice-ed: S NiebrzegowskaBartmińska. Wydawnictwo Uniwersytetu Marii CurieSkłodowskiej, Lublin, Poland, Pp. 199-231.

Bartmiński J, Łaszkiewicz M. 2018. Cebula (Allium серa). Słownik stereotypów i symboli ludowych. Vol. 2: Rośliny, Part: 2: Warzywa, przyprawy, rośliny przemysłowe. Overall concept and chief ed: J Bartmiński, vice-ed: S Niebrzegowska-Bartmińska. Wydawnictwo Uniwersytetu Marii CurieSkłodowskiej, Lublin, Poland, Pp. 295-311.

Bartmiński J, Niebrzegowska S. 1998. Profile a podmiotowa interpretacja świata. Profilowanie w języku i w tekście. Edited by J Bartmiński, R Tokarski. Wydawnictwo Uniwersytetu Marii CurieSkłodowskiej, Lublin, Poland, Pp. 211-223.

Bartmiński J, Niebrzegowska-Bartmińska S. 2013. Czy grzyb jest rośliną, czyli co znajdzie się w polu Rośliny w II tomie „Słownika stereotypów i symboli ludowych". Sapientia Ars Vivendi. Księga Jubileuszowa ofiarowana Profesor Annie Dąbrowskiej. Edited by A Burzyńska-Kamieniecka, A Libura. Oficyna Wydawnicza „Atut” -Wrocławskie Wydawnictwo Oświatowe, Wrocła, Poland, Pp. 4164. 
Bartmiński J, Prorok K. 2018. Groch (Pisum). Słownik stereotypów i symboli ludowych. Vol. 2: Rośliny, Part: 2:Warzywa, przyprawy, rośliny przemysłowe. Overall concept and chief ed: J Bartmiński, vice-ed: S Niebrzegowska-Bartmińska. Wydawnictwo Uniwersytetu Marii CurieSkłodowskiej, Lublin, Poland, Pp. 9-43.

Bielak A. 2019. Fiołek (Viola). Słownik stereotypów i symboli ludowych. Vol. 2: Rośliny, Part: 3: Kwiaty. Overall concept and chief ed: J Bartmiński, vice-ed: S Niebrzegowska-Bartmińska. Wydawnictwo Uniwersytetu Marii Curie-Skłodowskiej, Lublin, Poland, Pp. 87-96.

Burszta J. (ed). 1967. Kultura ludowa Wielkopolski. Vol. 3. Wydawnictwo Poznańskie, Poznań, Poland.

Bystroń JS. (ed). 1927. Pieśni ludowe z polskiego Śląska; Part 1: Pieśni balladowe. Polska Akademja Umiejętności, Kraków, Poland.

Cercha S. 1904. Poglądy ludu na przyrodę. Łopuszna nad Dunajcem. Wisła 18:811-812.

Ciszewski S. 1886. Lud rolniczo-górniczy z okolic Sławkowa w powiecie Olkuskim (Part 1). Zbiór Wiadomości do Antropologii Krajowej 10:187-336.

Dafni A. 2016. Myrtle (Myrtus communis) as a Ritual Plant in the Holy Land - a Comparative Study in Relation to Ancient Traditions. Economic Botany $X X: 1-13$.

Dafni A, Petanidou T, Vallianatou I, Kozhuharova E, Blanché C, Pacini E, Peyman M, Stevanovic ZD, Franchi GG, Benítez G. 2019. Myrtle, Basil, Rosemary, and Three-Lobed Sage as Ritual Plants in the Monotheistic Religions: an HistoricalEthnobotanical Comparison. Economic Botany.

Dejna K. 1978. Słownictwo ludowe z terenów województwa kieleckiego i łódzkiego. Rozprawy Komisji Językowej. Wydawnictwo Łódzkiego Towarzystwa Naukowego; 24:149-274.

Dekowski JP. 1978. Z badań nad problematyką wesela opoczyńskiego. Łódzkie Studia Etnograficzne 23:5-82.

Dekowski JP. 1988. Zwyczaje rodzinne i doroczne kaliszan w świetle konkursu folklorystycznego. Łódzkie Studia Etnograficzne 28:45-62.

Drabik W. 1990. Cztery pory życia (o współzależności obrzędów dorocznych i rodzinnych). Polska Sztuka Ludowa 1:15-30.

Dubisz S. 1977. Nazwy roślin w gwarach ostródzkowarmińsko-mazurskich. Zakład Narodowy im. Ossolińskich, Wrocław, Poland.
Dygacz A. 1987. Pieśni ludowe miasta Katowic. Źródła i dokumentacja. Katowickie Towarzystwo Społeczno-Kulturalne, Katowice, Poland.

Faulks PL. 1958. An Introduction to Ethnobotany. Moredale Publiations Limited, London, U.K.

Fischer A. 1921. Zwyczaje pogrzebowe ludu polskiego. Zakład Narodowy im. Ossolińskich, Lwów, Ukraine.

Forstner D. 1990. Świat symboliki chrześcijańskiej. Instytut Wydawniczy Pax, Warszawa, Poland.

Gaj-Piotrowski W. 1967. Kultura społeczna ludu z okolic Rozwadowa. Polskie Towarzystwo Ludoznawcze, Wrocław, Poland.

Gajek J. 1946. Polski atlas etnograficzny. Lud 36:408-412.

Gajek J. (ed). 1974. Polski Atlas Etnograficzny. Zeszyt V. Polska Akademia Nauk, Instytut Historii Kultury Materialnej, Warszawa, Poland.

Gajek J. (ed). 1981. Polski Atlas Etnograficzny. Zeszyt VI. Polska Akademia Nauk, Instytut Historii Kultury Materialnej, Warszawa, Poland.

Gerlich H. 1984. Narodziny, zaślubiny, śmierć: zwyczaje i obrzędy w katowickich rodzinach górniczych. Śląski Instytut Naukowy, Katowice, Poland.

Głaz A. 2013. Prostowanie zwierciadła. Przyczynek do (jeszcze?) niezaistniałej dyskusji nt. kondycji lubelskiej etnolingwistyki. Biuletyn PTJ LXIX:139151.

Grochowski M. 1993. Konwencje semantyczne a definiowanie wyrażeń językowych, Zakład Semiotyki Logicznej Uniwersytetu Warszawskiego „Znak Język - Rzeczywistość": Polskie Towarzystwo Semiotyczne, Warszawa, Poland.

Harshberger JW. 1896. The purposes of ethnobotany. Botanical Gazette 21:146-154.

Henslowa M. 1962. Rośliny dziko rosnące w kulturze ludu polskiego (Chenopodium, Atriplex, Urtica, Rumex, Sambucus). Polskie Towarzystwo Ludoznawcze, Wrocław, Poland.

Hrycyna E. 2019. Ruta (Ruta graveolens). Słownik stereotypów i symboli ludowych. Vol. 2: Rośliny, Part: 4: Zioła. Overall concept and chief ed: J Bartmiński, vice-ed: S Niebrzegowska-Bartmińska. Wydawnictwo Uniwersytetu Marii CurieSkłodowskiej, Lublin, Poland, Pp. 356-375.

Janicka-Krzywda U. 2001. Mirtowy wianek i nie tylko. Kwiaty 4:13. 
Kaczan A. 2019. Stokrotka (Bellis). Słownik stereotypów i symboli ludowych. Vol. 2: Rośliny, Part: 3: Kwiaty. Overall concept and chief ed: J Bartmiński, vice-ed: S Niebrzegowska-Bartmińska. Wydawnictwo Uniwersytetu Marii CurieSkłodowskiej, Lublin, Poland, Pp. 243-249.

Kantor J. 1907. Czarny Dunajec. Monografia etnograficzna. Materiały AntropologicznoArcheologiczne i Etnograficzne 9: 17-229.

Karłowicz J. 1900-1911. Słownik gwar polskich. Vol. 1-6. Nakładem Akademii Umiejętności, Kraków, Poland.

Karłowicz J, Kryński A, Niedźwiedzki W (ed). 19521953. Słownik języka polskiego. Vol. 1-8. Państwowy Instytut Wydawniczy, Warszawa, Poland.

Karwicka T. 1979. Kultura ludowa Ziemi Dobrzyńskiej. Państwowe Wydawnictwo Naukowe, Warszawa, Poland.

Kawalec. 1929. Zwyczaje ludu polskiego na Śląsku w okresie świąt Bożego Narodzenia. Zaranie Śląskie. Kwartalnik Literacki 5:236-242.

Kąś J. 2011. Słownik gwary orawskiej. Vol. 1-2. Księgarnia Akademicka, Kraków, Poland.

Kąś J. 2015-2018. Ilustrowany leksykon gwary i kultury podhalańskiej. Vol. 1-6. Bukowińskie Centrum Kultury „Dom Ludowy”, Małopolskie Centrum Kultury Sokół, Bukowina Tatrzańska, Poland.

Kielak O. [forthcoming]. Mirt (Myrtus). Słownik stereotypów i symboli ludowych. Vol. 2: Rośliny, Part: 6: Krzewy i krzewinki. Overall concept and chief ed: J Bartmiński, vice-ed: S NiebrzegowskaBartmińska. Wydawnictwo Uniwersytetu Marii CurieSkłodowskiej, Lublin, Poland.

Klepacki P. 2007. Etnobotanika w Polsce przeszłość i teraźniejszość. Analecta 16 (1-2):191245.

Knoop O. 1895. Podania i opowiadania z W. Ks. Poznańskiego [Part 4]. Wisła 9:470-513.

Kolberg O. 1876/1963. Dzieła wszystkie. Vol. 10: W. Ks. Poznańskie; Part 2. Polskie Wydawnictwo Muzyczne, Ludowa Spółdzielnia Wydawnicza, Kraków-Warszawa, Poland [original 1876].

Kolberg O. 1883/1962. Dzieła wszystkie. Vol. 16: Lubelskie; Part 1. Polskie Wydawnictwo Muzyczne, Ludowa Spółdzielnia Wydawnicza, KrakówWarszawa, Poland [orginal 1883].

Kolberg O. 1969. Dzieła wszystkie. Vol. 41: Mazowsze; Part 6. Edited by M Tarko. Polskie
Wydawnictwo Muzyczne, Ludowa Spółdzielnia Wydawnicza, Kraków-Warszawa, Poland.

Kolosova VB, Svanberg I, Kalle R, Strecker L, Özkan AMG, Pieroni A, Cianfaglione K, Molnár Z, Papp N, Łuczaj Ł, Dimitrova D, Šeškauskaitè D, Roper J, Hajdari A, Sõukand R. 2017. The bear in Eurasian plant names: motivations and models. Journal of Ethnobiology and Ethnomedicine 13:14.

Kopaliński W. 1985. Słownik mitów i tradycji kultury. Państwowy Instytut Wydawniczy, Warszawa, Poland.

Kopczyńska-Jaworska B. 1989. Zmiany wzorów kultury chłopskiej w miejskim środowisku robotniczym: zawarcie małżeństwa i obrzędowość weselna w Łodzi i Żyrardowie. Łódzkie Studia Etnograficzne 29:51-65.

Kowalska-Lewicka A. 1964. Etnobotanika. Etnografia Polska 8:207-214.

Kowalski P. 1998. Leksykon znaki świata. Omen, przesąd, znaczenie. Wydawnictwa Naukowe PWN, Warszawa-Wrocław, Poland.

Köhler P. 1993. Ankieta Józefa Rostafińskiego z 1883 roku dotycząca ludowego nazewnictwa i użytkowania roślin w Polsce. Analecta - Studia i Materiały z Dziejów Nauki II 2 (4): 7-119.

Köhler P. 2014. An Involuntary Ethnobotanist? Józef Rostafiński (1850-1928) and his research in Poland. Pioneers in European Ethnobiology. Edited by I Svanberg, Ł Łuczaj. Uppsala University, Uppsala, Sweden, Pp. 149-179.

Köhler P. 2018. Etnobotanika Podhala na podstawie ankiety Józefa Rostafińskiego (1850-1928) z 1883 r. Etnobiologia Polska 8:39-98.

Kujawska M, Klepacki, Łuczaj Ł. 2017. Fischer's Plants in folk beliefs and customs: a previously unknown contribution to the ethnobotany of the Polish-Lithuanian-Belarusian borderland. Journal of Ethnobiology and Ethnomedicine 13:20.

Kujawska M, Łuczaj Ł, Sosnowska J, Klepacki P. 2016. Rośliny w wierzeniach i zwyczajach ludowych. Słownik Adama Fischera. Polskie Towarzystwo Ludoznawcze, Wrocław, Poland.

Kujawska M, Łuczaj Ł, Typek J. 2015. Fischer's Lexicon of Slavic beliefs and customs: a previously unknown contribution to the ethnobotany of Ukraine and Poland. Journal of Ethnobiology and Ethnomedicine 11: 85.

Libera Z, Paluch A. 1993. Lasowiacki zielnik. Biblioteka Publiczna Miasta i Gminy Kolbuszowa, Kolbuszowa, Poland. 
Lipiński A. 1965. Pozostałości kultury tradycyjnej w łódzkich rodzinach robotniczych. Łódzkie Studia Etnograficzne 7:5-39.

Łęga W. 1933. Ziemia Malborska. Kultura ludowa. Kasa im. Mianowskiego, Instytut Popierania Nauki, Toruń-Warszawa, Poland.

Łozowski P. 1999. Panchronia, czyli językoznawstwo bez synchronii. Przeszłość w językowym obrazie świata. Edited by A Pajdzińska, P Krzyżanowski. Wydawnictwo Uniwersytetu Marii Curie-Skłodowskiej, Lublin, Poland, Pp. 25-50.

Łuczaj Ł. 2011. Herbal bouquets blessed on Assumption Day in south-eastern Poland: freelisting versus photographic inventory. Ethnobotany Research and Applications 9:1-25.

Łuczaj Ł. 2013. Etnobotanika w Polsce u progu XXI wieku. Wiadomości Botaniczne 57:9-15.

Łuczaj Ł. 2014. The Engineer of Ethnobotanical Cartography. Polish ethnographer Józef Gajek (1907-1987) and his contribution to our science. Pioneers in European Ethnobiology. Edited by I Svanberg, $Ł$ Łuczaj. Uppsala University, Uppsala, Sweden, Pp. 273-282.

Łuczaj Ł, Köhler P. 2011. Liście i inne zielone części dziko rosnących roślin w pożywieniu mieszkańców ziem polskich na podstawie ankiet Józefa Rostafińskiego (XIX w.) i Józefa Gajka (XX w.). Przegląd Historyczny 102 (4):733-770.

Marczewska M. 2012. Ja cię zamawiam, ja cię wypędzam... Choroba. Studium językowo-kulturowe. Instytut Filologii Polskiej UJK, Kielce, Poland.

Mayenowa MR (ed), Pepłowski F (vice-ed). 1982. Słownik polszczyzny XVI wieku. Vol. 14. Zakład Narodowy im. Ossolińskich, Wrocław-WarszawaKraków, Poland.

Nadmorski [Łęgowski J]. 1892. Kaszuby i Kociewie. Język, zwyczaje, przesądy, podania, zagadki i pieśni ludowe w północnej części Prus Zachodnich. Czcionkami Drukarni Dziennika Poznańskiego, Poznań, Poland.

Neppop-Ajdačić L. 2019. Goździk (Dianthus). Słownik stereotypów i symboli ludowych. Vol. 2: Rośliny, Part: 3: Kwiaty. Overall concept and chief ed: J Bartmiński, vice-ed: S NiebrzegowskaBartmińska. Wydawnictwo Uniwersytetu Marii CurieSkłodowskiej, Lublin, Poland, Pp. 99-108.

Niebrzegowska S. 1996. Polski sennik ludowy. Wydawnictwo Uniwersytetu Marii CurieSkłodowskiej, Lublin, Poland.

Niebrzegowska S. 2000. Przestrach od przestrachu. Rośliny w ludowych przekazach ustnych.
Wydawnictwo Uniwersytetu Marii CurieSkłodowskiej, Lublin, Poland.

Niebrzegowska-Bartmińska S. 2013. Ustalanie znaczeń symbolicznych w słowniku etnolingwistycznym. LingVaria 1(15):127-144.

Niebrzegowska-Bartmińska S. 2014. Od separacyjnego do holistycznego opisu językowego obrazu świata. Na marginesie dyskusji nad kształtem artykułów w „Leksykonie aksjologicznym Słowian i ich sąsiadów”. Wartości Słowian i ich sąsiadów. Vol. 3: Problemy eksplikowania i profilowania pojęć. Edited by I Bielińska-Gardziel, S NiebrzegowskaBartmińska, J Szadura. Wydawnictwo Uniwersytetu Marii Curie-Skłodowskiej, Lublin, Poland, Pp. 71102.

Niebrzegowska-Bartmińska S. 2018. Konopie (Cannabis sativa). Słownik stereotypów i symboli ludowych. Vol. 2: Rośliny, Part: 2: Warzywa, przyprawy, rośliny przemysłowe. Overall concept and chief ed: J Bartmiński, vice-ed: $\mathrm{S}$ Niebrzegowska-Bartmińska. Wydawnictwo Uniwersytetu Marii Curie-Skłodowskiej, Lublin, Poland, Pp. 425-454.

Niebrzegowska-Bartmińska S. 2019. Róża (Rosa). Słownik stereotypów i symboli ludowych. Vol. 2: Rośliny, Part: 3: Kwiaty. Overall concept and chief ed: J Bartmiński, vice-ed: S NiebrzegowskaBartmińska. Wydawnictwo Uniwersytetu Marii CurieSkłodowskiej, Lublin, Poland, Pp. 203-238.

Paluch A. 1985. Miejsce roślin w praktykach i zwyczajach związanych ze śmiercią człowieka na wsi polskiej. Etnobotanika. Materiały । Ogólnopolskiego Seminarium Etnobotanicznego, Kolbuszowa 19-20 VII 1980 r. Edited by A Paluch. Wydawnictwo Uniwersytetu Wrocławskiego, Kolbuszowa, Poland.

Paluch A. 1988. Świat roślin w tradycyjnych praktykach leczniczych wsi polskiej. Wydawnictwo Uniwersytetu Wrocławskiego, Wrocław, Poland.

Pelcowa H. 2017. Słownik gwar Lubelszczyzny. Vol. 5: Świat roślin. Wydawnictwo Uniwersytetu Marii Curie-Skłodowskiej, Lublin, Poland.

Piekarczyk D, Szadura J. 2019. Chaber (Centaurea). Słownik stereotypów i symboli ludowych. Vol. 2: Rośliny, Part: 3: Kwiaty. Overall concept and chief ed: J Bartmiński, vice-ed: S NiebrzegowskaBartmińska. Wydawnictwo Uniwersytetu Marii CurieSkłodowskiej, Lublin, Poland, Pp. 71-84.

Płatek P. (ed). 1976. Albośmy to jacy tacy. Zbiór pieśni Krakowiaków wschodnich i zachodnich. Krajowa Agencja Wydawnicza, Kraków, Poland. 
Podgórski A, Podgórska B. 2008. Słownik gwar śląskich: godómy po naszymu, czyli po śląsku. Wydawnictwo Kos, Katowice, Poland.

Pośpiech J. 1987. Zwyczaje i obrzędy doroczne na Śląsku. Instytut Śląski, Opole, Poland.

Prorok K. 2018a. Ogórek (Cucumis sativus). Słownik stereotypów i symboli ludowych. Vol. 2: Rośliny, Part: 2: Warzywa, przyprawy, rośliny przemysłowe. Overall concept and chief ed: J Bartmiński, vice-ed: S Niebrzegowska-Bartmińska. Wydawnictwo Uniwersytetu Marii Curie-Skłodowskiej, Lublin, Poland, Pp. 139-148.

Prorok K. 2018b. Kapusta (Brassica oleracea). Słownik stereotypów i symboli ludowych. Vol. 2: Rośliny, Part: 2: Warzywa, przyprawy, rośliny przemysłowe. Overall concept and chief ed: J Bartmiński, vice-ed: S Niebrzegowska-Bartmińska. Wydawnictwo Uniwersytetu Marii CurieSkłodowskiej, Lublin, Poland, Pp. 80-121.

Prorok K. 2018c. Marchew (Daucus carota). Słownik stereotypów i symboli ludowych. Vol. 2: Rośliny, Part: 2: Warzywa, przyprawy, rośliny przemysłowe. Overall concept and chief ed: J Bartmiński, vice-ed: S Niebrzegowska-Bartmińska. Wydawnictwo Uniwersytetu Marii Curie-Skłodowskiej, Lublin, Poland, Pp. 238-252.

Prorok K. 2019a. Lawenda (Lavandula). Słownik stereotypów i symboli ludowych. Vol. 2: Rośliny, Part: 3: Kwiaty. Overall concept and chief ed: J Bartmiński, vice-ed: S Niebrzegowska-Bartmińska. Wydawnictwo Uniwersytetu Marii CurieSkłodowskiej, Lublin, Poland, Pp. 123-130.

Prorok K. 2019b. Kaczeniec (Caltha palustris). Słownik stereotypów i symboli ludowych. Vol. 2: Rośliny, Part: 3: Kwiaty. Overall concept and chief ed: J Bartmiński, vice-ed: S NiebrzegowskaBartmińska. Wydawnictwo Uniwersytetu Marii CurieSkłodowskiej, Lublin, Poland, Pp. 110-113.

Pyla G. 2004. Prymicje jako obrzęd przejścia. Lud 88:79-90.

Reinfuss R. (ed). 1965. Nad rzeką Ropą. Zarys kultury ludowej powiatu gorlickiego. Wydawnictwo Literackie, Kraków, Poland.

Rogowska E. 1998. Kaszubskie nazwy roślin uprawnych. Wydawnictwo Uniwersytetu Gdańskiego, Gdańsk, Poland.

Rokossowska Z. 1889. O świecie roślinnym wyobrażenia, wierzenia i podania ludu ruskiego na Wołyniu we wsi Jurkowszczyzna. Zbiór Wiadomości do Antropologii Krajowej 13:163-199.

Rostafiński J. 1888. Burak i barszcz. Nazwa i rzecz. Ich pochodzenie i znaczenie w kolei czasów.
Rozprawy i Sprawozdania Wydziału Filologicznego Akademii Umiejętności 8:314-339.

Rostafiński J. 1895. Zielnik czarodziejski to jest zbiór przesądów o roślinach. Zbiór Wiadomości do Antropologii Krajowej 18:1-191.

Rostafiński J. 1911. Ćwikła i buraki w Polsce. Sprawozdania z Czynności i Posiedzeń Akademii Umiejętności w Krakowie 16 (8):13.

Rostafiński J. 1916. O nazwach oraz użytkach ćwikły, buraków i barszczu. Nakładem Akademii Umiejętności, Kraków, Poland.

Sobierajski Z. 1960. Teksty gwarowe z Nowego Kramska w powiecie sulechowskim. Literatura Ludowa 4:38-43.

Steuer F. 1937. Narzecze baborowskie. Nakładem Polskiej Akademii Umiejętności, Kraków, Poland.

Sychta B. 1967-1976. Słownik gwar kaszubskich na tle kultury ludowej. Vol. 1-7. Zakład Narodowy im. Ossolińskich, Wrocław, Poland.

Svanberg I, Łuczaj Ł. 2014. Activity Contexts and Biocultural Domains. Pioneers in European Ethnobiology. Edited by I Svanberg, $\measuredangle$ Łuczaj. Uppsala University, Uppsala, Sweden, Pp. 9-26.

Szadura J. 2019. Bratek (Viola tricolor). Słownik stereotypów i symboli ludowych. Vol. 2: Rośliny, Part: 3: Kwiaty. Overall concept and chief ed: J Bartmiński, vice-ed: S Niebrzegowska-Bartmińska. Wydawnictwo Uniwersytetu Marii CurieSkłodowskiej, Lublin, Poland, Pp. 62-70.

Szeląg F. 1934. Boży rok w zwyczajach i obrzędach ludu żywieckiego w okresie dorocznych świąt. Orli Lot 15:138-153.

Szulczewski JW. 1966. „Pieśni bez końca”. Zbiór tekstów folklorystyczno-etnograficznych. Łysiak W. (ed). PSO, Poznań, Poland.

Szymańska J. 1991. Podlaskie pieśni włóczebne. Etnolingwistyka 5:97-134.

Szymańska J. (ed). 2012. Polska pieśń i muzyka ludowa. Źródła i materiały. Vol. 5: Podlasie; Part 2: Teksty pieśni powszechnych. Instytut Sztuki PAN, Warszawa, Poland.

Śmiełowski S. 1967. Kleklimanki. Opowieści ludowe ze Śląska Opolskiego. Śląsk, Katowice, Poland.

Świątkowska A. 1978. Zwyczaje i obrzędy rodzinne regionu łowickiego $\mathrm{w}$ procesie zmian ( $\mathrm{z}$ dokumentacji terenowej). Łódzkie Studia Etnograficzne 20:27-79.

Tabakowska E. 2001. Kognitywizm. Obrazki z polskiej sceny. Glossos. 
https://slaviccenters.duke.edu/sites/slaviccenters.du ke.edu/files/media_items_files/tabakowska.original. pdf. Accessed 10 Sept 2019.

Tabakowska E. 2013. A linguistic picture, image, or view of 'Polish Cognitive Studies'. The Linguistic Worldview. Ethnolinguistics, Cognition, and Culture. Edited by A Głaz, DS Danaher, P Łozowski. Walter de Gruyter GmbH, London, U.K., Pp. 321-338.

Toeppen M. 1892. Wierzenia mazurskie [Part 2]. Wisła 6:391-420.

Tołstoj NI. 1992. Język a kultura (Niektóre zagadnienia słowiańskiej etnolingwistyki). Etnolingwistyka 5:15-25.

Udziela S. 1890. Lud polski w powiecie Ropczyckim w Galicyi [Part 1]. Zbiór Wiadomości do Antropologii Krajowej 14:1-136.

Udziela S. 1994. Ziemia Biecka. Lud polski w powiatach gorlickim i grybowskim. Sądecka Oficyna Wydawnicza WOK, Nowy Sącz, Poland.

Waniakowa J. 2015. Nazwy zwierząt w nazwach roślin. Dialog pokoleń w języku potocznym, w języku wsi i miasta, w literaturze, w publicystyce, w tekstach kultury. Edited by E Wierzbicka-Piotrowska. Wydział Polonistyki Uniwersytetu Warszawskiego, Warszawa, Poland, Pp. 187-194.

Wronicz J (ed). 1995. Słownik gwarowy Śląska Cieszyńskiego. Towarzystwo Miłośników Wisły, Towarzystwo Miłośników Ustronia, Wisła-Ustroń, Poland.

Zborowski J. 1932. Ludoznawcze przyczynki z góralszczyzny. Lud 31:65-120.

Zinken J. 2009. The Ethnolinguistic School of Lublin and Anglo-American cognitive linguistics. Bartmiński J. Aspects of Cognitive Ethnolinguistics. Equinox Publishing Ltd, London and Oakville, U.K., Pp. 1-5.

\section{Nagrania terenowe:}

Jasiennik Stary 1977. Nagranie terenowe, Jasiennik Stary, woj. lubelskie, pow. Biłgoraj, 1977, zdeponowane w Pracowni „Archiwum Etnolingwistyczne" UMCS w Lublinie.

Niedźwiada 1977. Nagranie terenowe, Niedźwiada, woj. lubelskie, pow. Lubartów, 1977, zdeponowane w Pracowni „Archiwum Etnolingwistyczne” UMCS w Lublinie.

Wietlin 1988. Nagranie terenowe, Wietlin, woj. podkarpackie, pow. Jarosław, 1988, zdeponowane w Pracowni „Archiwum Etnolingwistyczne” UMCS w Lublinie. 